OPEN ACCESS

Edited by:

Tomoko Nozoye,

Meiji Gakuin University, Japan

Reviewed by:

Neil J. Willey,

University of the West of England, Bristol, United Kingdom

Chul Min Kim,

Wonkwang University, South Korea

*Correspondence:

Hiroki Ra

raihiro@akita-pu.ac.jp

Specialty section:

This article was submitted to

Plant Traffic and Transport,

a section of the journal

Frontiers in Plant Science

Received: 31 January 2020 Accepted: 07 April 2020

Published: 13 May 2020

Citation:

Rai $H$ and Kawabata M (2020)

The Dynamics of Radio-Cesium

in Soils and Mechanism of Cesium Uptake Into Higher Plants: Newly Elucidated Mechanism of Cesium Uptake Into Rice Plants.

Front. Plant Sci. 11:528.

doi: 10.3389/fp/s.2020.00528

\section{The Dynamics of Radio-Cesium in Soils and Mechanism of Cesium Uptake Into Higher Plants: Newly Elucidated Mechanism of Cesium Uptake Into Rice Plants}

\author{
Hiroki Rai* and Miku Kawabata \\ Department of Biological Production, Faculty of Bioresource Sciences, Akita Prefectural University, Akita, Japan
}

Soil radio-cesium (Cs) contamination caused by nuclear accidents is a major public concern. In this review, we presented the behavior of radio-Cs in soils, the relationship between $\mathrm{Cs}^{+}$and potassium $(\mathrm{K})$ ion uptake from soils, and the $\mathrm{Cs}^{+}$uptake model proposed previously. Finally, we introduced the newly elucidated mechanism of $\mathrm{Cs}^{+}$ uptake in rice plants and compared it with the previously proposed $\mathrm{Cs}^{+}$uptake model. Cs is a trace element in soil. It is toxic to plants when absorbed at high concentrations, although this rarely occurs under normal environmental conditions. Nevertheless, radioCs released during nuclear weapon tests or nuclear power plant accidents is absorbed by plants, thus entering the food chain. As $\mathrm{Cs}^{+}$strongly binds to the frayed edge sites of illitic clays in soil, it is hardly moved by the infiltration of rainwater. However, plants have a strong ability for inorganic ions uptake, causing re-diffusion of radio-Cs ${ }^{+}$ into ecosystems and radioactive contamination of food. It is hypothesized that $\mathrm{Cs}^{+}$is absorbed by plants through the same mechanism implemented in $\mathrm{K}^{+}$uptake. However, the dynamics of the two elements do not always coincide in their transition from soil to plants and inside the plants. A previously proposed model of Cs uptake by higher plants stated that $\mathrm{Cs}^{+}$is absorbed through high affinity potassium (HAK) family of transporters and voltage-insensitive cation ( $\mathrm{VIC}$ ) channels. A knockout line of a HAK transporter gene (oshak1) in rice revealed that the HAK transporter OsHAK1 is the main route of $\mathrm{Cs}^{+}$influx into rice plants, especially in low-potassium conditions. The $\mathrm{K}^{+}$uptake rates did not differ greatly between the oshak1 and wildtype. On the surface of rice roots, potassiumtransport systems other than OsHAK1 make little or no contribution to $\mathrm{Cs}^{+}$uptake. It is almost certain that OsAKT1 does not mediate the Cs uptake. Under normal soil conditions, $80-90 \%$ of Cs uptake into the roots is mediated by OsHAK1 and the rest by $\mathrm{VIC}$ channels. Except for the difference between the contribution ratio of HAK and VIC channels in Cs uptake, these results are consistent with the conventional model.

Keywords: cesium, potassium transporters, HAK, KIR channels, VIC channels, radio-cesium, rice, Fukushima 


\section{INTRODUCTION}

Cesium (Cs) is a Group I alkali metal along with sodium (Na) and potassium $(\mathrm{K})$. Its chemical properties are very similar to those of $\mathrm{K}$, which is one of the macronutrient elements of plants. Generally, the solubility of $\mathrm{K}$ and $\mathrm{Cs}$ salts is very high, and both are always present as monovalent ions in the natural environment. The concentration of $\mathrm{K}^{+}$is in the range from 100 to $150 \mathrm{mM}$ in the cytoplasm of plant cells, where it regulates the osmotic pressure of the cells. The controlled osmotic fields are essential for enzymatic reactions and maintaining the structure of nucleic acids. Although $\mathrm{Cs}^{+}$has physical properties similar to $\mathrm{K}^{+}, \mathrm{Cs}^{+}$does not provide the same as $\mathrm{K}^{+}$in vital cell activities. As Cs concentration of the cells increases, the cytotoxicity increases due to the decrease in or inhibition of the enzyme activity (White and Broadley, 2000; Hampton et al., 2004; Maathuis, 2009).

The concentration of stable Cs isotope $\left({ }^{133} \mathrm{Cs}\right)$ in the environment is generally low (up to $25 \mu \mathrm{g} / \mathrm{g}$ soil) and not harmful to plants or human health. However, Cs uptake by plants may become a public concern when radio-Cs $\left({ }^{134} \mathrm{Cs},{ }^{137} \mathrm{Cs}\right)$ is released by nuclear weapons tests or nuclear power plant accidents. Plants can absorb the radio-Cs in soil and incorporate it into the food chain, where it may cause internal exposure to $\beta$ and $\gamma$ radiation during its radioactive decay (White and Broadley, 2000).

The research on the absorption of $\mathrm{Cs}^{+}$from soil by plants has been intensive over the past several decades. $\mathrm{Cs}^{+}$and $\mathrm{K}^{+}$ compete during uptake by plants and a $\mathrm{Cs}^{+}$uptake model has been proposed based on the analysis of $\mathrm{K}^{+}$transporters. After the nuclear accident caused by the Great East Japan Earthquake in 2011, research on $\mathrm{Cs}^{+}$absorption in rice has been advanced in Japan. This helped to elucidate the mechanism of $\mathrm{Cs}^{+}$absorption by rice roots.

In this review, we introduce the outline of $\mathrm{Cs}^{+}$dynamics in soil and the results of research on the absorption mechanism in plants. Then, we compare the conventional $\mathrm{Cs}^{+}$absorption model of plants with the newly elucidated mechanism of $\mathrm{Cs}^{+}$ uptake into rice.

\section{CESIUM AND RADIO-CESIUM EXISTENCE IN THE ENVIRONMENT}

The concentration of Cs $\left({ }^{133} \mathrm{Cs}\right)$ in soil is low. Although Cs is toxic to plants when absorbed in high concentration as its intracellular concentration becomes high, such a phenomenon rarely occurs under normal environmental conditions. The toxicity of Cs to living organisms is not from the stable isotope $\left({ }^{133} \mathrm{Cs}\right)$, but from the artificially produced radioactive Cs $\left({ }^{134} \mathrm{Cs}\right.$,

$\left.{ }^{137} \mathrm{Cs}\right)$. Atmospheric nuclear tests have already been prohibited, but the commercial nuclear power reactors account for $10 \%$ of electricity produced in the world.

We have experienced widespread radionuclide contaminations caused by the nuclear power plant accidents in the Chernobyl Nuclear Power Plant, Ukraine, in 1986 and in the Fukushima Daiichi Nuclear Power Plant, Japan, in 2011. Radio-Cs was a common problem in both nuclear accidents.
In the Chernobyl accident, the containment vessel exploded, exposing the reactor core to the atmosphere and releasing numerous radionuclides such as radioactive xenon $\left({ }^{133} \mathrm{Xe}\right)$, iodine $\left({ }^{131} \mathrm{I}\right)$, Cs $\left({ }^{134,137} \mathrm{Cs}\right)$, strontium $\left({ }^{90} \mathrm{Sr}\right)$, zirconium $\left({ }^{95} \mathrm{Zr}\right)$, ruthenium $\left({ }^{103,106} \mathrm{Ru}\right)$, and plutonium $\left({ }^{239} \mathrm{Pu}\right)$ (International Atomic Energy Agency [IAEA], 2003-2005; Imanaka, 2016). Among these nuclides, radio-Cs contaminated a large area and became a major source of radioactive contamination of the food chain (Fesenko et al., 2007).

In the Fukushima disaster, the containment vessel itself was not severely damaged, but ${ }^{133} \mathrm{X},{ }^{131} \mathrm{I}$, and ${ }^{134,137} \mathrm{Cs}$ leaked from the containment vessel and were released into the atmosphere by venting or by hydrogen explosion of the building. ${ }^{133} \mathrm{Xe}$, which is a gas, and ${ }^{131} \mathrm{I}$ and ${ }^{134,137} \mathrm{Cs}$, both with low boiling points, were released in large amounts and widely dispersed. Of these three elements, ${ }^{133}$ Xe diffused into the atmosphere, and

${ }^{131}$ I was not detected in a few months after the accident because of its short half-life (8.04 days). However, the half-life of radioCs is long (2.06 years for ${ }^{134} \mathrm{Cs} ; 30.17$ years for ${ }^{137} \mathrm{Cs}$ ), and it tends to strongly adsorb to the soil, thus polluting the fallout area for a long time (Chino et al., 2011; Beresford et al., 2016; Imanaka, 2016).

There are two problems related to radio-Cs pollution of the environment. One is elicited through external exposure, in which $\beta$ and $\gamma$ rays are emitted by the decay of radio-Cs, so air dose increases, exposing people to these harmful rays. The other problem is related to internal exposure generated through absorption of radio-Cs by crops and its transfer into the food chain, contaminating food and posing health problems (Fesenko et al., 2007; Beresford et al., 2016). The rate of radio-Cs absorption from ingested contaminated food is extremely high; the transfer factor is 65-90\% (Henrichs et al., 1989; Beresford et al., 2000). In mammals, radio-Cs, similar to $\mathrm{K}$, is taken up into the blood and transferred into tissues such as muscles, but its fecal and urinary excretion is low. In the body, radio-Cs has a considerably long half-life (45-200 days, with an average of 90 days), exposing the internal organs to radiation from radio-Cs (Henrichs et al., 1989). In addition, herbivores absorb radio-Cs from pasture fields, which results in contamination of dairy products and meat. In Chernobyl, the consumption of foods containing radio-Cs was the major source of public exposure via milk and other animal products (Beresford et al., 2000; Fesenko et al., 2007; Fesenko et al., 2015; Figure 1). In Fukushima, the provisional guideline levels for radio-Cs were specified immediately after the accident and all agricultural products were measured for radioactivity before shipment. The products contaminated with excess radiation have not been circulated (Nihei, 2013). Internal exposure by foods originates from the absorption of radio-Cs by plants, so it is important to know the dynamics of Cs from soils to plants.

\section{DYNAMICS OF CESIUM AND RADIO-Cs IN THE ENVIRONMENT}

Cesium has a strong ionization tendency, and its salts generally have high solubility. The radio-Cs released from nuclear power 


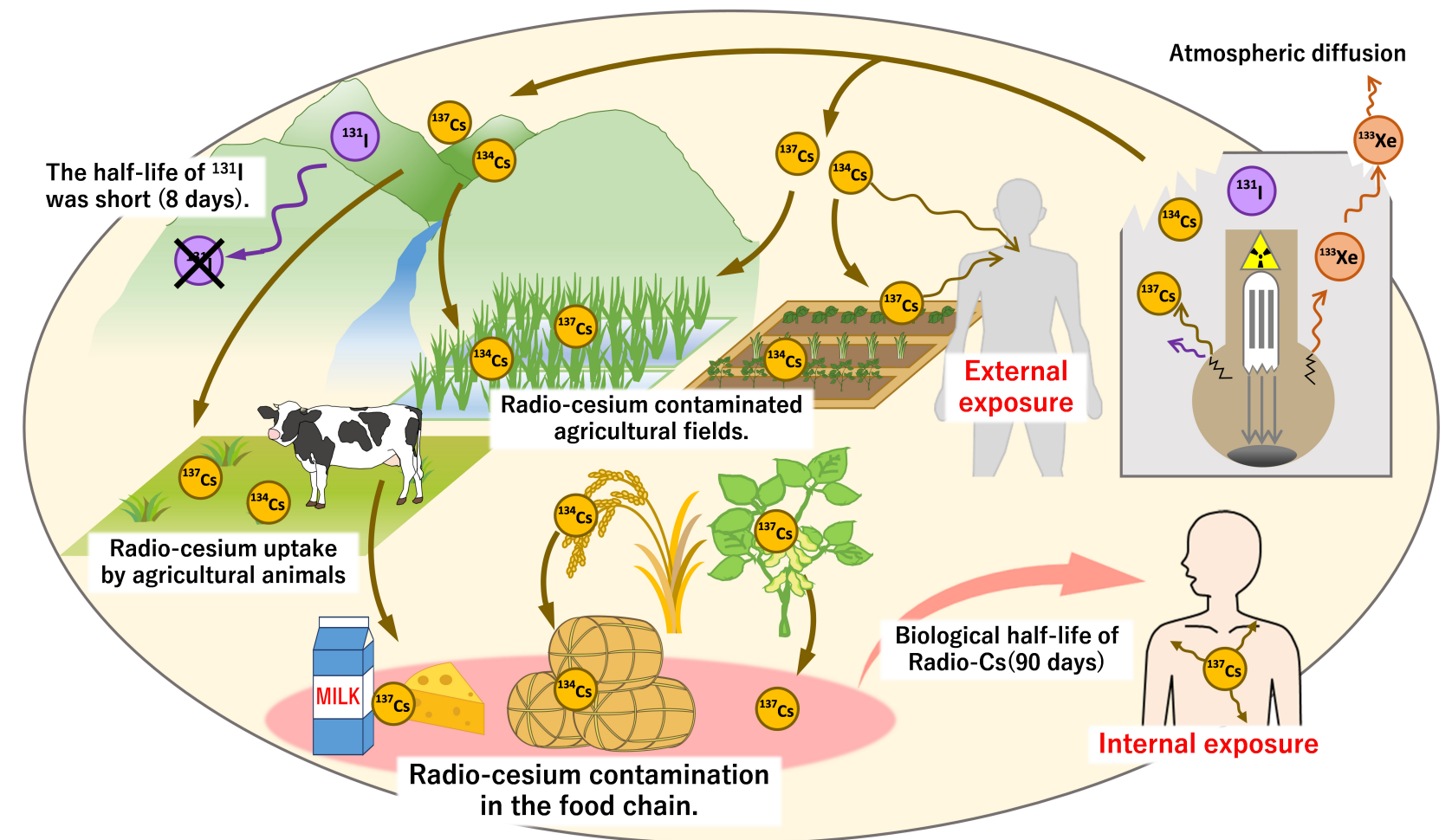

FIGURE 1 | Diffusion of radio-Cs and contamination of soil and food due to the Fukushima nuclear plant accident. At the time of the nuclear power plant accident, gaseous ${ }^{133} \mathrm{Xe}$ as well as ${ }^{131} \mathrm{I},{ }^{134} \mathrm{Cs}$, and ${ }^{137} \mathrm{Cs}$ with low boiling point easily leaked. These nuclides were released and spread widely when a hydrogen explosion damaged the plant building. ${ }^{133}$ Xe diffused quickly into the atmosphere, and ${ }^{131}$ I could not be detected within a few months due to its short half-life. In contrast, the half-lives of ${ }^{134,137} \mathrm{Cs}$ are long, allowing its persistence in the environment for long periods. The decay of ${ }^{134,137} \mathrm{Cs}$ caused external exposure to emitted $\gamma$-rays. Internal exposure also occurred through the ingestion of contaminated food. Absorption of ${ }^{134,137} \mathrm{Cs}$ by plants (agricultural crops) allowed its entry into the food chain resulting in the contamination of grains, vegetables, dairy products, and many more food sources. Due to the long biological half-life of Cs in humans (approximately 90 days), it is necessary to monitor these isotopes in soil, plants, and foods.

plants is deposited from the atmosphere onto the ground. The particles containing radio-Cs fall on the soil surface in crop fields or on the leaves and bark of forest trees, and eventually enter the organic matter layer with rainfall. Ultimately, as the organic matter decomposes, radio-Cs migrates into the A layer containing clay minerals, where it behaves differently from $\mathrm{K}^{+}$ and $\mathrm{Na}^{+}$(Takahashi et al., 2019).

Clay and humus contained in soil are negatively charged and have cation exchangeable sites that commonly adsorb cations such as $\mathrm{Cs}^{+}$and $\mathrm{K}^{+}$(Figure 2, left panel). Furthermore, there are sites in the soil that specifically adsorb $\mathrm{Cs}^{+}$(Cremers et al., 1988). Clay minerals in the soil have a layered structure of aluminosilicates, with the layers whose surfaces are negatively charged and held together by cations such as $\mathrm{K}^{+}$and $\mathrm{Mg}^{2+}$. As soil weathers, aluminosilicates are precipitated, the ions between the layers are gradually released from the outer edge, and the layers slightly open at the edge of the clay mineral. In illitic clays, this edge is named frayed edge site, and it shows a specific adsorption affinity for $\mathrm{Cs}^{+}$whose ionic radius is large and hydration radius is small. The adsorption of $\mathrm{Cs}^{+}$by frayed edge sites is more than 1000-fold greater than that for $\mathrm{K}^{+}$, and it is almost irreversible (Yamaguchi, 2014; Figure 2, right panel).
However, soils lacking illitic clays have much higher Cs availability for plant uptake. Thus, Radio-Cs Interception Potential (RIP) was proposed as the quantitative measure of radio-Cs retention in soils (Cremers et al., 1988). In typical clay soils containing illitic clays, the number of this frayed edge sites is much higher than that required for the immobilization of radio-Cs (Cremers et al., 1988; Vandebroek et al., 2012). It is assumed that most of the stable isotope $\mathrm{Cs}^{+}$is trapped by this frayed edge sites. Newly supplied $\mathrm{Cs}^{+}$, such as radio-Cs, is hardly moved in the soil because it is captured by these sites and thereby immobilized. In the absence of human disturbance, most of the radioactive $\mathrm{Cs}^{+}$from the nuclear accidents has been concentrated in the top several centimeters of the soil (Almgren and Isaksson, 2006; Takahashi et al., 2019).

The concentration of stable isotope $\mathrm{Cs}\left({ }^{133} \mathrm{Cs}\right)$ in a typical soil is $2.5 \mathrm{mg} \mathrm{kg}^{-1}$ and the concentration of $\mathrm{Cs}^{+}$in soil solution is lower than $10 \mu \mathrm{g} \mathrm{L}^{-1}$ (75 nM) (Tsukada et al., 2002; Rai et al., 2017). The soil concentration of radio-Cs is considerably lower than the concentration of ${ }^{133} \mathrm{Cs}$.

In Japan, a reference value was set for protection during the continuous consumption of radioactive contaminated food after the Fukushima nuclear accident. The concentration of radio-Cs in soil where radioactive contamination of crops would exceed 


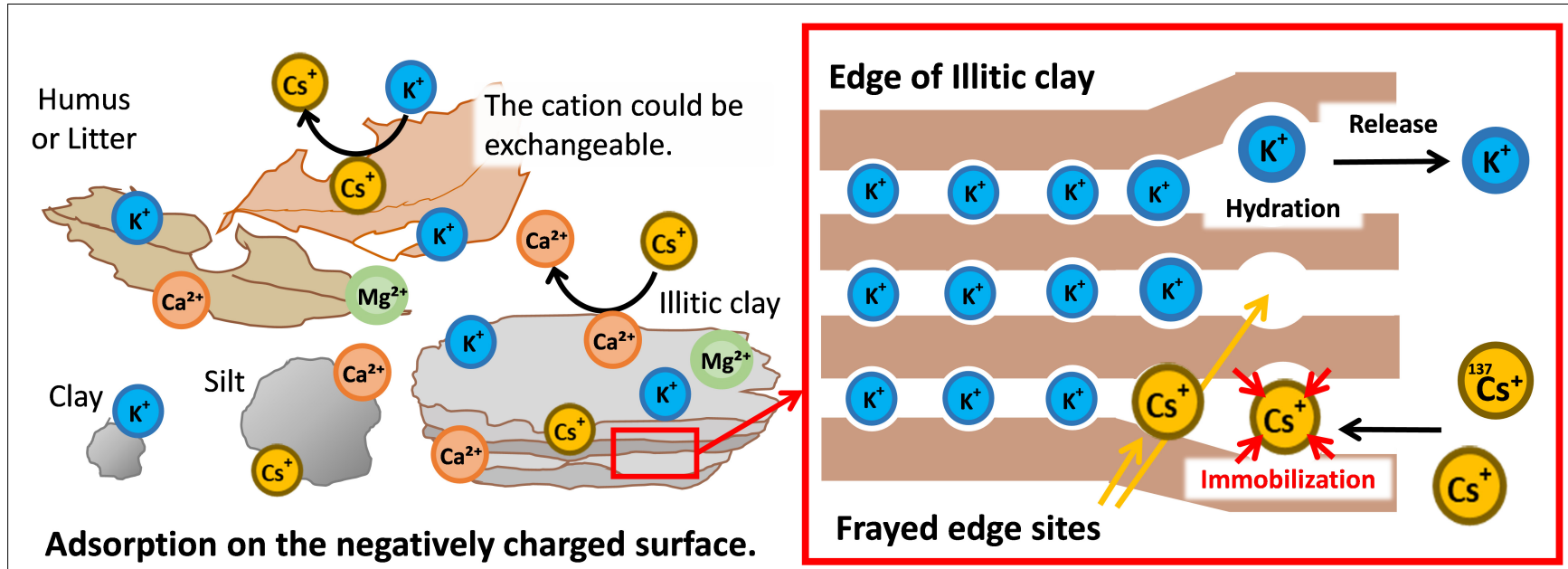

FIGURE 2 | Dynamics of radio-Cs in soil and the quantitative relationship between potassium and Cs. In soil, radio Cs+ is adsorbed through the negative charges of organic substances such as humus or clay similarly to other cations such as $\mathrm{K}^{+}$and $\mathrm{Ca}^{2}$. In addition, $\mathrm{Cs}^{+}$is strongly immobilized (captured) on the mica's frayed edge sites over time. As a result, radio $\mathrm{Cs}^{+}$is vertically immobile and mostly accumulates on the top soil.

the reference value could be estimated from the transfer factor and the reference value of crops $\left(100 \mathrm{~Bq} \mathrm{~kg}^{-1}\right.$ in rice). In the case of rice, the transfer factor for brown rice from the soil is from 0.004 to 0.065 (Kondo et al., 2015). At 0.065 as transfer factor, the radio-Cs concentration in the soil is estimated to $1540 \mathrm{~Bq} \mathrm{~kg}^{-1}$ soil. The concentration of radio-Cs in soils where agriculture could resume is expected to be less than a several thousand $\mathrm{Bq} \mathrm{kg}{ }^{-1}$ soil.

In soils contaminated with ${ }^{134} \mathrm{Cs}$ or ${ }^{137} \mathrm{Cs}$ at $10,000 \mathrm{~Bq} \mathrm{~kg}-1$ soil, the weight of Cs can be calculated using the following formula.

$$
\begin{aligned}
10,000 \mathrm{~Bq} ;{ }^{134} \text { Cs in soil }\left(\mathrm{Bq} \mathrm{kg}^{-1}\right)=10,000 \times 60 \times 60 \times 24 \\
\times 365 \times 2.06 \times 2^{\wedge}(1 / 2) /\left(6.02 \times 10^{23}\right) \\
=1.54 \mathrm{pmol} \mathrm{kg}{ }^{-1}=206 \mathrm{pg} \mathrm{kg}^{-1} \\
10,000 \mathrm{~Bq} ;{ }^{137} \mathrm{Cs} \text { in soil }\left(\mathrm{Bq} \mathrm{kg}^{-1}\right)=10,000 \times 60 \times 60 \times 24 \\
\times 365 \times 30.2 \times 2^{\wedge}(1 / 2) /\left(6.02 \times 10^{23}\right) \\
=23 \mathrm{pmol} \mathrm{kg}{ }^{-1}=3.15 \mathrm{ng} \mathrm{kg}^{-1}
\end{aligned}
$$

Even if the concentration of radioactive Cs in the soil is $10,000 \mathrm{~Bq} / \mathrm{kg}$, the amount of ${ }^{134} \mathrm{Cs}$ and ${ }^{137} \mathrm{Cs}$ is $206 \mathrm{pg} \mathrm{kg}^{-1}$ and $3.15 \mathrm{ng} \mathrm{kg}^{-1}$, respectively, which is negligible for the amount of stable isotope Cs. Cs that is the focus of this review is ${ }^{133} \mathrm{Cs}$ radioactively labeled with a considerably lower concentration of ${ }^{134,137}$ Cs (Figure 3, bottom right panel).

It is well known that $\mathrm{Cs}^{+}$competes with $\mathrm{K}^{+}$during plant uptake and it is absorbed by plants through the same mechanism as $\mathrm{K}^{+}$. The quantitative relationship between $\mathrm{K}^{+}$and $\mathrm{Cs}^{+}$ controls for the $\mathrm{Cs}^{+}$uptake of plants (Figure 3, left panel).

$\mathrm{K}$ is the fourth most abundant element in the lithosphere, and its ion, $\mathrm{K}^{+}$, is supplied by the soil clay minerals. The total $\mathrm{K}$ concentration in paddy fields is approximately $8000 \mathrm{mg} \mathrm{kg}-1$ (5000-13,000 $\mathrm{mg} \mathrm{kg}^{-1}$ ) (Tsukada et al., 2002). The concentration of exchangeable $\mathrm{K}^{+}$is an indicator of plant available $\mathrm{K}^{+}$. The exchangeable $\mathrm{K}^{+}$concentration in 178 agricultural soils (95 paddy fields and 83 upland fields in Japan) ranged from 43 to $1304 \mathrm{mg} \mathrm{kg}^{-1}$, with a median of $209 \mathrm{mg} \mathrm{kg}^{-1}$ (Kitagawa et al., 2017). The concentration of $\mathrm{K}^{+}$in soil solution is less than $10 \%$ of exchangeable $\mathrm{K}^{+}$concentration. Furthermore, the concentration of $\mathrm{K}^{+}$in soil solution is variable in the rhizosphere as the rate of exchangeable $\mathrm{K}^{+}$release is slower than the rate of $\mathrm{K}^{+}$uptake by plants; $10-100 \mu \mathrm{M} \mathrm{K}^{+}$is contained in soil solution (Sparks and Huang, 1985; Ashley et al., 2005; Gomez-Porras et al., 2012; Figure 3, upper right panel).

As described above, $\mathrm{K}^{+}$concentration in soil solutions is $10-$ $100 \mu \mathrm{M}$ and that of $\mathrm{Cs}^{+}$is less than $100 \mathrm{nM}$. The difference between the $\mathrm{K}^{+}$and $\mathrm{Cs}^{+}$concentrations in soil solution is large and the K/Cs ratio is approximately $10^{3}$ in the soil solution (Figure 3, bottom right panel). Some studies on $\mathrm{Cs}^{+}$uptake by plants for functional analysis, such as a selectivity of ions of the $\mathrm{K}^{+}$transporter, were conducted at equal concentration of $\mathrm{Cs}^{+}$ and $\mathrm{K}^{+}$, which therefore differed greatly from the concentration of $\mathrm{Cs}^{+}$in the environment. In the dynamics of radio-Cs between soils and plants, this difference should be considered.

\section{THE MECHANISM OF $\mathrm{K}^{+}$UPTAKE IN HIGHER PLANTS}

Since the time Collander (1941) proposed his theory that $\mathrm{K}^{+}$ and $\mathrm{Cs}^{+}$are absorbed by roots through the same pathway, the research on $\mathrm{Cs}^{+}$uptake has always been associated with the analysis of the $\mathrm{K}^{+}$uptake mechanism. As described in section "Introduction," $\mathrm{K}^{+}$mainly regulates the osmotic pressure of plant cells, and its concentration in a cell itself affects the activity of enzymes. Plants use various $\mathrm{K}^{+}$transporters on the cell membrane to adjust the intracellular $\mathrm{K}^{+}$concentration depending on the plant part or tissue. Thus, the mechanism 


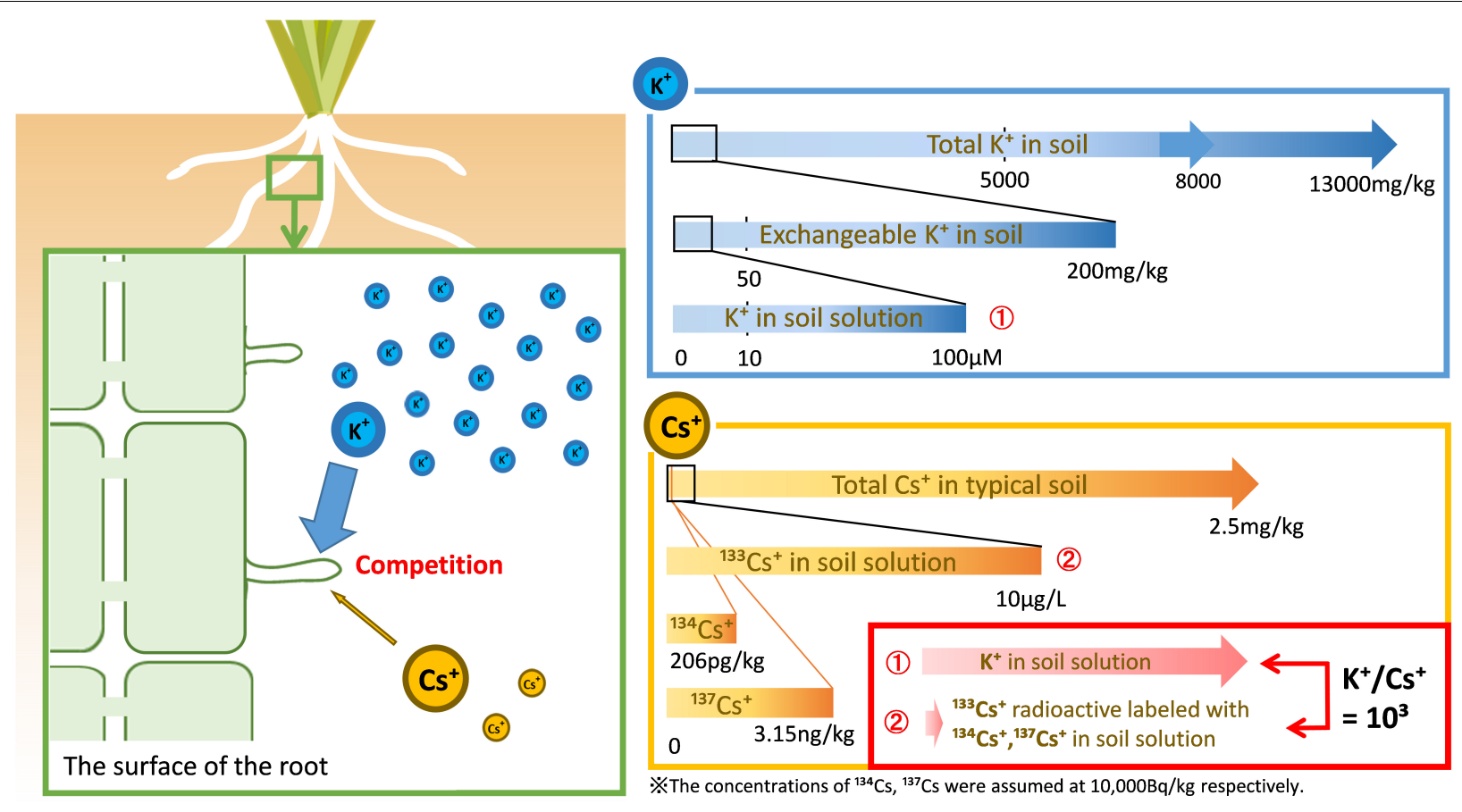

FIGURE 3 | The Cs targeted in this review. The amount of stable isotope Cs $\left({ }^{133} \mathrm{Cs}\right)$ in a typical soil is approximately $2.5 \mathrm{mg} / \mathrm{kg}$ but its concentration in soil solution is lower than $10 \mu \mathrm{g} / \mathrm{L}\left(75 \mathrm{nM}\right.$ ) (Tsukada et al., 2002; Rai et al., 2017). Our target in this review is radioactively labeled ${ }^{133} \mathrm{Cs}$ and a much smaller amount of ${ }^{134,137} \mathrm{Cs}$. In contrast to radio $\mathrm{Cs}^{+}$, potassium is an environmentally abundant element supplied from soil clay minerals, at concentrations of 5000-13,000 mg/kg soil (Tsukada et al., 2002). The exchangeable $\mathrm{K}^{+}$available to plants is approximately $200 \mathrm{mg} / \mathrm{kg}$ soil, while $10-100 \mu \mathrm{M} \mathrm{K}^{+}$is retained in soil solution (Sparks and Huang, 1985; Gomez-Porras et al., 2012; Kitagawa et al., 2017). The actual K/Cs ratio is approximately $10^{3}$ in the soil solution.

of intracellular $\mathrm{K}^{+}$concentration adjustment is intricate and involves a complex $\mathrm{K}^{+}$transport network in which a considerable number of $\mathrm{K}^{+}$transporters continuously cooperate to provide required concentrations of $\mathrm{K}^{+}$to all plant cells (Maathuis, 2009).

Genomic analyses identified 35 genes in Arabidopsis and 50 genes in rice controlling $\mathrm{K}^{+}$transporters and the uptake or excretion of $\mathrm{K}^{+}$across cell membranes (Amrutha et al., 2007; Yang et al., 2009). There are a large number of $\mathrm{K}^{+}$transporters, divided into five major $\mathrm{K}^{+}$transporter families based on their functional type (Mäser et al., 2001). To date, only a part of the $\mathrm{K}^{+}$uptake and transport pathways and their many transporters have been elucidated. One of them is $\mathrm{K}^{+}$uptake in roots.

The uptake of $\mathrm{K}^{+}$into plant cells using $\mathrm{K}^{+}$transporters is driven by the $\mathrm{H}^{+}$concentration gradient and electric potential difference caused by $\mathrm{H}^{+}$transport out of the cells. $\mathrm{K}^{+}$ transporters that take $\mathrm{K}^{+}$into the cells are mainly divided into a carrier type and channel type. Carrier-type $\mathrm{K}^{+}$transporters include the KUP/HAK/KT (or shorter HAK) family of high affinity $\mathrm{K}^{+}$transporters, which transport $\mathrm{K}^{+}$into the cells by cotransport with $\mathrm{H}^{+}$. The transport by HAK requires binding of $\mathrm{K}^{+}$ and $\mathrm{H}^{+}$to the HAK protein itself; therefore, the absorption curve plotting the external $\mathrm{K}^{+}$concentration and the rate of $\mathrm{K}^{+}$carried into the cells fits the Michaelis-Menten equation (Maathuis and Sanders, 1994). Carrier-type $\mathrm{K}^{+}$transporters have high affinity for $\mathrm{K}^{+}$and can transfer $\mathrm{K}^{+}$into the cells even at low extracellular $\mathrm{K}^{+}$concentrations. The HAK family is the most numerous among the $\mathrm{K}^{+}$transporters, and it is encoded by genes such as
AtHAK1-AtHAK13 in Arabidopsis and OsHAK1-OsHAK27 in rice (Gupta et al., 2008; Yang et al., 2009).

In contrast, the channel type of $\mathrm{K}^{+}$transporters carries $\mathrm{K}^{+}$ into the cells when the extracellular $\mathrm{K}^{+}$concentration is relatively high. There are two types of $\mathrm{K}^{+}$channels: an inward rectifying $\mathrm{K}^{+}(\mathrm{KIR})$ channel that transports $\mathrm{K}^{+}$into the cells, and an outward rectifying $\mathrm{K}^{+}(\mathrm{KOR})$ channel that flows $\mathrm{K}^{+}$out of the cells (Rodríguez-Navarro, 2000; Szczerba et al., 2009).

Generally, the concentration of $\mathrm{K}^{+}$in plant cells is $100 \mathrm{mM}$ or higher, while its concentration in soil solution is less than $1 \mathrm{mM}$ even in $\mathrm{K}^{+}$-rich soils. Therefore, the KIR channel functions (rectifying property) only when the membrane potential becomes more negative than the equilibrium potential of $\mathrm{K}^{+}$and the direction of $\mathrm{K}^{+}$transmission is predetermined. Channel-type $\mathrm{K}^{+}$ transporters do not require the binding of $\mathrm{K}^{+}$to channel proteins and can pass more than $10^{6}$ ions per second.

It has been shown that switching between the carrier type and channel type during $\mathrm{K}^{+}$uptake into plant roots depends on $\mathrm{K}^{+}$ concentration in the soil. At low soil $\mathrm{K}^{+}$concentrations (less than $1 \mathrm{mM}$ ), HAK family such as OsHAK1 and OsHAK5 in rice and AtHAK5 and AtKUP7 in Arabidopsis is mainly activated (Pyo et al., 2010). However, at high soil $\mathrm{K}^{+}$concentrations $(1 \mathrm{mM}$ or more), channels such as OsAKT1 in rice and AtAKT1 in Arabidopsis, belonging to the KIR channel family, are the main transporters of $\mathrm{K}^{+}$(Nieves-Cordones et al., 2016; Figure 4). For example, the $\mathrm{Km}$ of AtHAK5 was $15-24 \mu \mathrm{M} \mathrm{K}^{+}$, while that of AKT1 was $0.88 \mathrm{mM}$ (Gierth et al., 2005). 


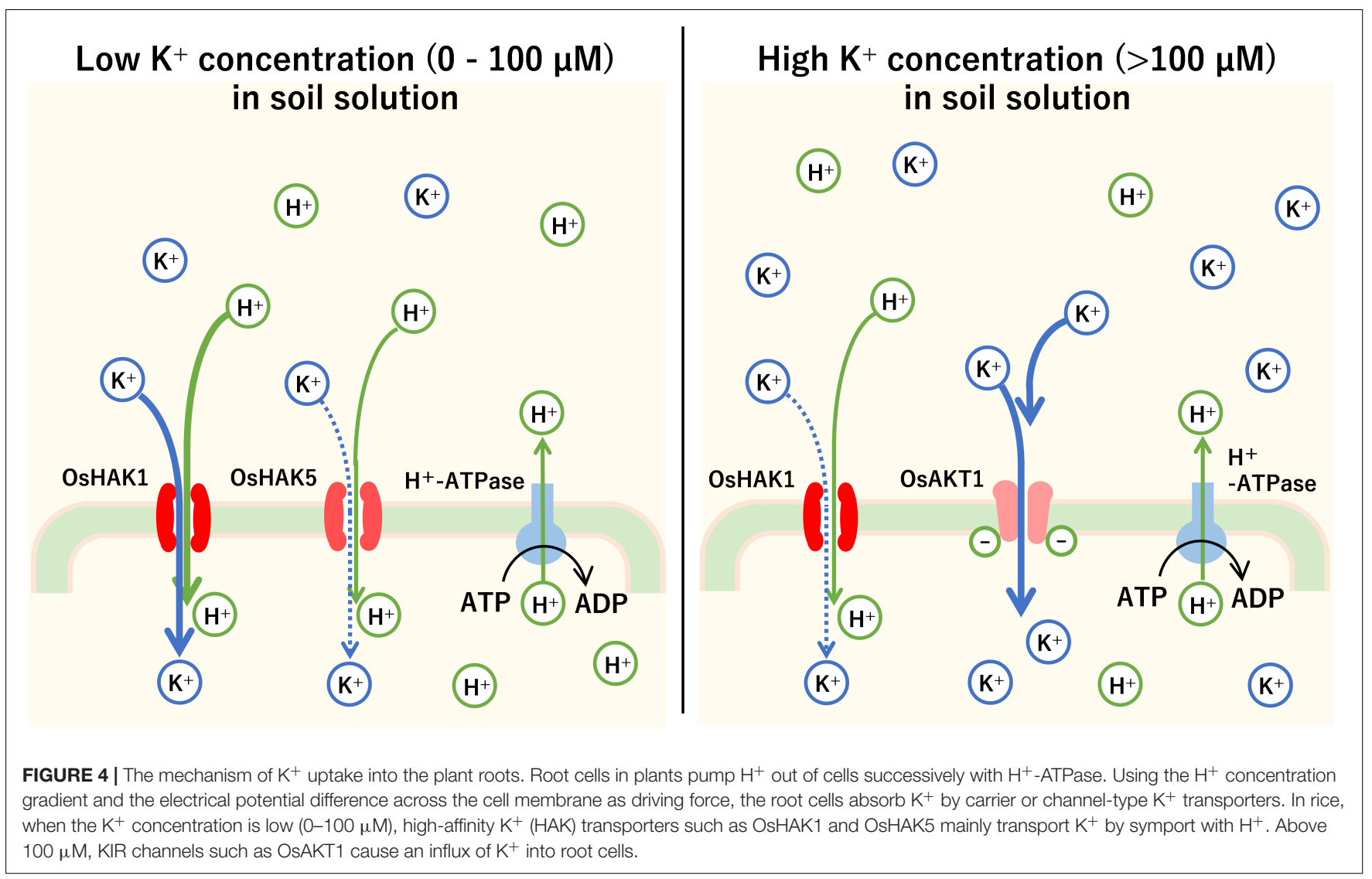

However, of the 27 HAK transporters in rice, the expression levels of OsHAK1, 7, and 16 are always high in rice roots, whereas the other HAK transporters are highly expressed during $\mathrm{K}^{+}$deficiency (Okada et al., 2008). Thus, not all routes of $\mathrm{K}^{+}$uptake are unknown. After absorption into root cells, $\mathrm{K}^{+}$ is moved from epidermal cells into cambium via cytoplasmic communication, and then released from the adjacent vessel cells through the KOR channel.

\section{CESIUM PERMEABILITY OF POTASSIUM TRANSPORTERS}

Transport of $\mathrm{Cs}^{+}$by $\mathrm{K}^{+}$transporters has been investigated by competition analysis in various plants by altering the ionic composition of hydroponic solutions, by electrophysiological methods using microelectrodes, and by investigating $\mathrm{Cs}^{+}$uptake characteristics of knockout mutants for $\mathrm{K}^{+}$transporters in model plants such as Arabidopsis. Studies employing the first two types of experiments are detailed in a review by White and Broadley (2000).

Since the time Collander (1941) proposed his theory about $\mathrm{K}^{+}$and $\mathrm{Cs}^{+}$uptake by roots, the uptake of these alkali metal ions was analyzed in hydroponic cultivations of barley and wheat. A study found that the rate of $\mathrm{Cs}^{+}$influx under different $\mathrm{Cs}^{+}$ concentrations can be described by the sum of two MichaelisMenten hyperbolae (Epstein, 1972). This suggests that $\mathrm{Cs}^{+}$may be absorbed into the roots by two types of $\mathrm{K}^{+}$transporters (high affinity and low affinity) having different $K_{\mathrm{m}}$. Shaw and Bell (1989) examined the concentration dependence of $\mathrm{Cs}^{+}$ influx into excised wheat roots and proposed the existence of two distinct $\mathrm{Cs}^{+}$influx isotherms. These authors reported that at excessive $\mathrm{Cs}^{+}$concentrations, the $\mathrm{Cs}^{+}$influx into the roots increases linearly with increasing $\mathrm{Cs}^{+}$concentration in the hydroponic solution, and they suggested that this second uptake system had lower affinity (Shaw and Bell, 1989).

The inhibition of $\mathrm{Cs}^{+}$influx by other ions has also been analyzed. The inhibition increased in the following order: $\mathrm{Li}^{+}<\mathrm{Na}^{+}<\mathrm{NH}_{4}^{+}<\mathrm{Rb}^{+} \leq \mathrm{K}^{+}$(Bange and Overstreet, 1960; Handley and Overstreet, 1961; Shaw and Bell, 1991). For divalent ions, the inhibition increased in the following order: $\mathrm{Ca}^{2+}<\mathrm{Mg}^{2+} \leq \mathrm{Ba}^{2+}$ (Handley and Overstreet, 1961), although the inhibition by divalent ions was incomplete. In spinach, an increase in the $\mathrm{Ca}^{2+}$ and $\mathrm{Mg}^{2+}$ concentrations significantly decreased $\mathrm{Cs}^{+}$uptake (Smolders et al., 1997).

Thus, it is possible that $\mathrm{Cs}^{+}$influx is associated with several $\mathrm{K}^{+}$transporters that may be inhibited by $\mathrm{Ca}^{2+}$ concentration. Cs is taken up by at least two types of transporters with different properties. However, it should be highlighted that in the studies utilizing hydroponics, the concentration of $\mathrm{Cs}^{+}$used in the experiments was sometimes much higher than that found in soil environments under normal conditions (less than $10 \mathrm{ppb} ; 75 \mathrm{nM}$ $\mathrm{Cs}^{+}$in soil solution), since these studies focus on the difference in the uptake rate between $\mathrm{K}^{+}$and $\mathrm{Cs}^{+}$. 
Electrochemical studies have shown that high-affinity HAK, low-affinity KIR channels, KOR channels, and voltage-insensitive cation channels (VIC) are $\mathrm{Cs}^{+}$permeable (White and Broadley, 2000). The ratio of $\mathrm{Cs}^{+}$permeability to $\mathrm{K}^{+}$influx of $\mathrm{KIR}$ channel in barley is $0.39-0.43$ and much lower, at 0.07, in Arabidopsis (Wegner and Raschke, 1994; Maathuis and Sanders, 1995). Cs permeability of KIR channels is lower than that of $\mathrm{K}^{+}$. Furthermore, increasing $\mathrm{Cs}^{+}$concentration inhibits $\mathrm{K}^{+}$permeation of KIR channels (Bregante et al., 1997; White, 1997).

The genes for several KIR channels have been cloned and expressed in Xenopus oocytes, yeast, and other cell types to study the characteristics of KIR channels electrophysiologically (Dreyer et al., 1999). Cation influx through KIR channels is inhibited in a voltage-dependent manner by extracellular $\mathrm{Cs}^{+}$(Ichida and Schroeder, 1996; Dreyer et al., 1999). Therefore, although $\mathrm{Cs}^{+}$can physically diffuse through the KIR channels, practically it can hardly permeate from the soil solution in the natural environment (White and Broadley, 2000).

VIC channels have non-selective cation permeability and voltage independence (insensitivity). The permeability of $\mathrm{Cs}^{+}$ through the VIC channels in rye roots was 0.85 when that of $\mathrm{K}^{+}$was defined as 1.0 (White and Tester, 1992). Cation influx through the VIC channels is insensitive to $\mathrm{Cs}^{+}$, but is partly inhibited by $\mathrm{Ca}^{2+}, \mathrm{Ba}^{2+}$, and other divalent ions (Roberts and Tester, 1997; White, 1997, 1999; Davenport and Tester, 2000). These characteristics correspond to the inhibition of $\mathrm{Cs}^{+}$influx by divalent ions.

Finally, we introduce the results of the mutant analysis of the model plant Arabidopsis thaliana. In Arabidopsis, deletion mutant lines of $\mathrm{K}^{+}$transporters such as HAK and AKT have been obtained to study their contribution to $\mathrm{Cs}^{+}$influx.

AtHAK5 is a high-affinity $\mathrm{K}^{+}$transporter that mainly absorbs $\mathrm{K}^{+}$at low extracellular $\mathrm{K}^{+}$concentrations. The AtHAK5 deletion significantly reduced $\mathrm{Cs}^{+}$absorption, but $\mathrm{Cs}^{+}$absorption was not significantly changed in AtAKT1 deletion mutants (Broadley et al., 2001; Qi et al., 2008). However, $\mathrm{Cs}^{+}$uptake in athak5 mutants during $\mathrm{K}^{+}$deficiency did not decrease significantly, suggesting that $\mathrm{Cs}^{+}$was absorbed by other $\mathrm{K}^{+}$transporters (Qi et al., 2008). Recently, it was reported that, when grown on radioactive Cs-contaminated soil, the amount of $\mathrm{Cs}^{+}$uptake by athak 5 is significantly lower than that of the wild type (Tanoi et al., 2019).

The rate of $\mathrm{K}^{+}$uptake was examined in athak5 and atakt1 single and double mutants. At $\mathrm{K}^{+}$concentrations lower than $0.01 \mathrm{mM}$, only AtHAK5 is involved in $\mathrm{K}^{+}$uptake, whereas at $\mathrm{K}^{+}$concentrations from 0.01 to $0.05 \mathrm{mM}$, both AtHAK5 and AtAKT1 are activated in $\mathrm{K}^{+}$uptake (Rubio et al., 2008, 2010). This suggested that AtAKT1 and other low-affinity $\mathrm{K}^{+}$transporters absorb $\mathrm{K}^{+}$at higher $\mathrm{K}^{+}$concentrations. In addition, the double athak5 and atakt1 mutants were able to grow at $\mathrm{K}^{+}$concentrations higher than $0.05 \mathrm{mM}$, suggesting that $\mathrm{K}^{+}$transporters other than AtHAK5 and AtAKT1 absorb $\mathrm{K}^{+}$and complement for the lack of the two $\mathrm{K}^{+}$transporters.

Caballero et al. (2012) reported that a $\mathrm{Ca}^{2+}$ sensitive transport system mediates low-affinity $\mathrm{K}^{+}$uptake in the atakt1 plants. The low affinity system probably belonging to the VIC channels may mediate the $\mathrm{K}^{+}$uptake in athak5, atakt1 plants.

In summary

I. $\mathrm{Cs}^{+}$is absorbed by the same mechanism as $\mathrm{K}^{+}$, and their relationship is competitive.

II. Certain $\mathrm{Cs}^{+}$influx pathways are also inhibited by divalent ions such as $\mathrm{Ca}^{2+}$.

III. $\mathrm{Cs}^{+}$and $\mathrm{K}^{+}$are not absorbed into the plant roots equally. It is also hypothesized that $\mathrm{Cs}^{+}$inhibits the $\mathrm{K}^{+}$influx through KIR channels. $\mathrm{Cs}^{+}$permeability differs for HAK, KIR, and VIC channels.

IV. There are at least two $\mathrm{Cs}^{+}$influx pathways into the roots (in wheat). The $\mathrm{Cs}^{+}$concentration dependence of $\mathrm{Cs}^{+}$influx into the roots could be drawn by the sum of two hyperbolae.

$\mathrm{V} . \mathrm{K}^{+}$uptake systems have a high level of redundancy in plants. If one of $\mathrm{K}^{+}$transporters is inactivated, $\mathrm{K}^{+}$influx is complemented by other $\mathrm{K}^{+}$transporters (HAK, AKT, VIC). Similarly, $\mathrm{Cs}^{+}$uptake system may involve multiple $\mathrm{K}^{+}$transporters.

White and Broadley (2000) proposed the $\mathrm{Cs}^{+}$uptake model, which was based on the characteristics of each type of $\mathrm{K}^{+}$ transporters (including VIC channels). The model predicted that the VIC channel and the HAK family mainly absorb $\mathrm{Cs}^{+}$into the root, and KIR channels, such as AKT1, are almost unrelated to the $\mathrm{Cs}^{+}$uptake (White and Broadley, 2000). However, in order to fully prove the model, it is necessary to create a plant in which each pathway has been deleted by techniques such as mutation or genome editing and examine the effect of gene deletions on $\mathrm{Cs}^{+}$influx. Ultimately, the goal would be to create a plant that does not absorb $\mathrm{Cs}^{+}$. Unfortunately, this has not been achieved before Fukushima.

\section{Cs UPTAKE MECHANISM INTO RICE ROOTS}

In the post-Fukushima studies, cultivation tests of many rice varieties in Cs-contaminated soils were conducted promptly to examine the differences in Cs uptake between varieties (Ohmori et al., 2014; Ono et al., 2014). Cs accumulation in the straw and brown rice of numerous varieties was analyzed, and the results revealed wide differences in $\mathrm{Cs}$ accumulation between varieties and large fluctuations in a cultivation year. These studies could not identify the causative genes for low and high Cs accumulation.

The analyses conducted in rice fields established no correlation between the concentrations of radio-Cs in soils and the amount of radio-Cs absorbed by rice plants. However, there was a correlation between the amounts of exchangeable $\mathrm{K}^{+}$ in the soils and the radio-Cs absorbed by rice plant (Kato et al., 2015; Kohyama et al., 2015; Kondo et al., 2015). The $\mathrm{K}^{+}$levels in the soils have a greater effect on the Cs uptake of plants than the concentration of radio-Cs in the soil.

Our research group separated the mutants with low $\mathrm{Cs}^{+}$ uptake and identified the causative gene. Elemental analysis 
of brown rice in 8027 mutants, which were induced by chemical mutation treatment, isolated a mutant with low $\mathrm{Cs}^{+}$uptake whose Cs concentration in brown rice was less than $10 \%$ of the wild type (Rai et al., 2017). OsHAK1, a member of the high-affinity HAK family expressed in roots, was identified as the causative gene. During hydroponic cultivation with multiple $\mathrm{K}^{+}$concentrations, the $\mathrm{Cs}^{+}$influx into the roots of oshak1 was significantly reduced by less than $1 / 8$ of the $\mathrm{Cs}^{+}$influx in wild type under low to normal soil $\mathrm{K}^{+}$concentrations. When this mutant was cultivated in a paddy field with high ${ }^{134,137} \mathrm{Cs}$ and low $\mathrm{K}^{+}$concentration, the ${ }^{137} \mathrm{Cs}$ of wild-type brown rice was $44 \mathrm{~Bq} / \mathrm{kg}$, whereas that of oshak1 was lower than the detection limit $(4.92 \mathrm{~Bq} / \mathrm{kg})$. Although the absorption of $\mathrm{Cs}^{+}$decreased, the absorption of $\mathrm{K}^{+}$was not significantly different from that of the wild type (Rai et al., 2017; Figure 5). This indicated that other $\mathrm{K}^{+}$ transporters complemented the $\mathrm{K}^{+}$uptake of OsHAK1. It has been also suggested that $\mathrm{K}^{+}$transporters other than OsHAK1 expressed on the surface of rice roots (mainly OsAKT1) hardly absorb $\mathrm{Cs}^{+}$. This is in agreement with the results of $\mathrm{Cs}^{+}$ permeability analysis in higher plants (Wegner and Raschke, 1994; Maathuis and Sanders, 1995).

The contribution of OsHAK1 to $\mathrm{K}^{+}$absorption increases under low $\mathrm{K}^{+}$conditions (50-55\% in the range of 50-100 $\mu \mathrm{M}$ $\mathrm{K}^{+}$and $30 \%$ at $1 \mathrm{mM} \mathrm{K}^{+}$) (Chen et al., 2015). The expression of OsHAK1 is induced 8-12-fold under $\mathrm{K}^{+}$deficiency, but suppressed under increased external $\mathrm{K}^{+}$concentration (Okada et al., 2008; Chen et al., 2015). These findings suggest that the use of potassium fertilizer not only reduces the $\mathrm{Cs}^{+}$uptake rate by increasing the $\mathrm{K}^{+}: \mathrm{Cs}^{+}$ratio, but also reduces the $\mathrm{Cs}^{+}$uptake by suppressing OsHAK1 expression.

The contribution of OsHAK1 for $\mathrm{Cs}^{+}$uptake has been also analyzed by reverse genetic techniques. The knockout lines that have lost the function of OsHAK1 created by CRISPRCas9 genome editing did not depolarize even when the roots were immersed in $\mathrm{Cs}^{+}$solutions with different concentrations (Nieves-Cordones et al., 2017). This indicated that $\mathrm{Cs}^{+}$was not absorbed into the root cells and the root membrane potential remained unaffected. It has also been reported that, when cultivated on $\mathrm{K}^{+}$-deficient soil contaminated with radio-Cs, the amount of ${ }^{134,137} \mathrm{Cs}$ absorbed was significantly lower than that of the wild type (Nieves-Cordones et al., 2017).

Both the forward and reverse gene techniques identified the same causative gene, revealing that most of the $\mathrm{Cs}^{+}$uptake in rice plants takes place via OsHAK1. Cs absorption could be reduced by indirectly suppressing HAK expression (Ishikawa et al., 2017). From the mutants irradiated with accelerated carbon ions, a low-Cs mutant was obtained that could reduce the radioCs uptake to about $30 \%$ of that of the wild type. The causative gene in this mutant was OsSOS2. This gene encodes a kinase that phosphorylates OsSOS1 $\left(\mathrm{Na}^{+} / \mathrm{H}^{+}\right.$antiporter) in rice root cells. Considering that OsSOS1 is activated by phosphorylation, knockout of OsSOS2 inactivates OsSOS1 and reduces the $\mathrm{Na}^{+}$ extrusion from roots. Increased intracellular $\mathrm{Na}^{+}$concentration is sensed by the cell as an increase in osmotic pressure, which triggers the cell to suppresses the expression of $\mathrm{K}^{+}$transporters such as HAK (OsHAK1, OsHAK5), OsAKT1, and OsHKT2.
It ultimately results in a decreased $\mathrm{Cs}^{+}$influx through these $\mathrm{K}^{+}$transporters. It has been shown that the stress caused by increasing $\mathrm{Na}^{+}$concentration in the root cells can also reduce Cs uptake in rice (Ishikawa et al., 2017). Thus, the mechanism of salt tolerance in rice can also be used to suppress $\mathrm{Cs}^{+}$uptake.

\section{Cs ABSORPTION IN OTHER HIGHER PLANTS}

Most of the radio-Cs that had fallen to land after the Fukushima nuclear accident entered the forest ecosystem. Therefore, it is also important to examine the absorption of radio-Cs in trees. An interesting dynamics of $\mathrm{Cs}^{+}$transport was revealed in the model forest tree poplar. The poplar does not change its $\mathrm{K}^{+}$ absorption during both long-day period and short-day period. However, the rate of $\mathrm{Cs}^{+}$uptake by poplar treated for 6 weeks on short days decreased to about $1 / 4$ of that in poplar treated for 9 days on a long day. Furthermore, the expression levels of major HAK and VIC channels did not change, suggesting that the tree may have an unknown $\mathrm{Cs}^{+}$absorption pathway (Noda et al., 2016).

After absorption into root cells, $\mathrm{K}^{+}$and $\mathrm{Cs}^{+}$are moved to cambium via cytoplasmic communication, and then released from the adjacent vessel cells via the KOR channels. One of the KOR channels, stelar $\mathrm{K}^{+}$outward rectifying channel (SKOR), has been identified in Arabidopsis. The SKOR is involved in the permeation of $\mathrm{K}^{+}, \mathrm{Rb}^{+}$, and $\mathrm{Cs}^{+}$. However, as the results were obtained by heterologous expression, the pathway of $\mathrm{Cs}^{+}$ in the plant body could not be elucidated (Gaymard et al., 1998; Johansson et al., 2006).

The molecular recognition of $\mathrm{Cs}^{+}$and $\mathrm{K}^{+}$in the $\mathrm{K}^{+}$ transporter has also been reported. Mutations were randomly introduced by PCR in cDNA synthesized from AtHAK5 of A. thaliana and heterologously expressed in yeast. When amino acid substitution occurred between the second and third transmembrane regions containing the $\mathrm{K}^{+}$binding hole, the selectivity of $\mathrm{K}^{+}$was 100 -fold higher than that for $\mathrm{Na}^{+}$or $\mathrm{Cs}^{+}$(Alemán et al., 2014). This points to a possibility that the selectivity of the high-affinity $\mathrm{K}^{+}$transporter for alkali metal ions can be further improved, and that only $\mathrm{K}^{+}$is incorporated into the cell by editing the amino acid sequence of HAK by mutagenesis. It may be possible to produce plants with $\mathrm{K}^{+}$ transporters that are highly selective toward $\mathrm{K}^{+}$absorption (as well as plants that preferentially accumulate $\mathrm{Cs}^{+}$). The plant $\mathrm{K}^{+}$transporter may have undergone evolutionary pressure for selective permeability of alkali metal ions.

\section{COMPARING THE PATHWAY OF $\mathbf{C s}^{+}$ UPTAKE IN RICE ROOTS WITH THE MODEL PROPOSED BY WHITE AND BROADLEY}

White and Broadley (2000) proposed a model for $\mathrm{Cs}^{+}$uptake, in which VIC channels contribute most of the $\mathrm{Cs}^{+}$influx under 


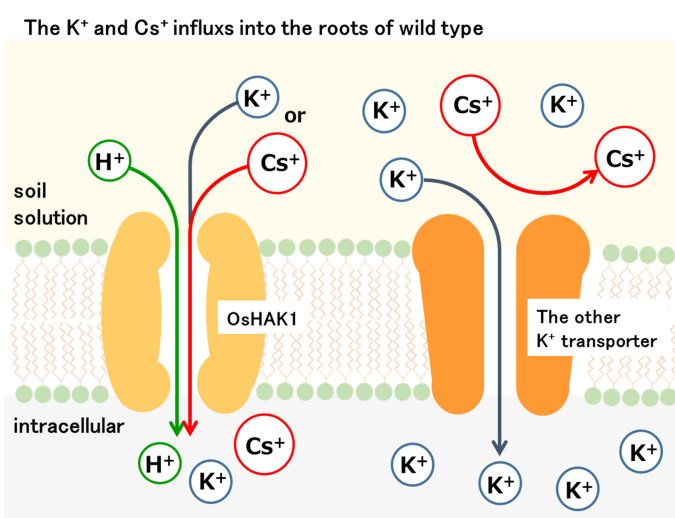

The $\mathrm{K}^{+}$and $\mathrm{Cs}^{+}$influxs into the roots of OsHAK1 knockout mutant

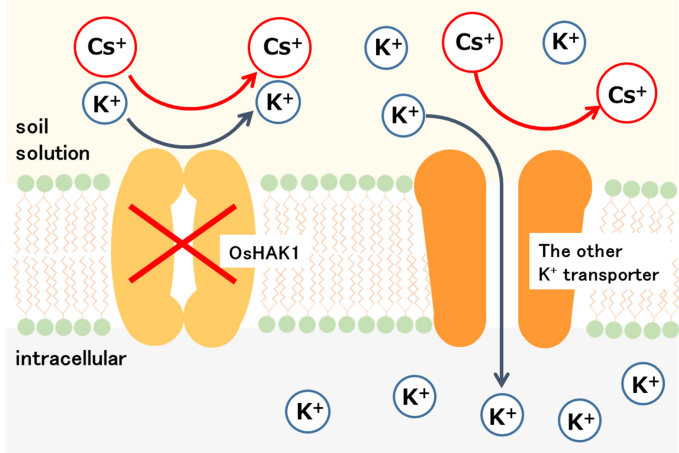

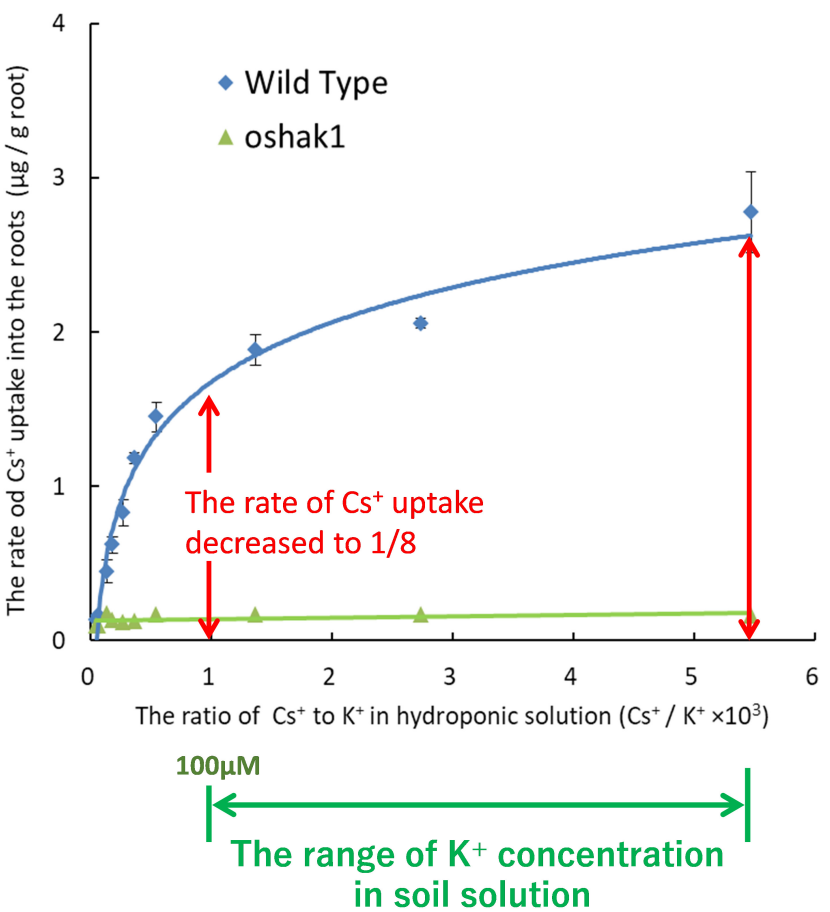

in soil solution

FIGURE 5 | The newly elucidated mechanism of $\mathrm{Cs}$ uptake in the rice plants. Upper left side: The root cells of rice (wild type) absorb $\mathrm{K}^{+}$and $\mathrm{Cs}^{+}$through $\mathrm{OsHAK1}$ at extracellular $\mathrm{K}^{+}$concentration below $100 \mu \mathrm{M}$. Lower left side: OsHAK1 knockout mutants could not absorb $\mathrm{K}^{+}$and $\mathrm{Cs}^{+}$through OsHAK1. However, the rate of $\mathrm{K}^{+}$uptake was maintained and the uptake was complemented by $\mathrm{K}^{+}$transporters other than OsHAK1. Possibly, other $\mathrm{K}^{+}$transporters other than OsHAK1 in the membrane did not permeate $\mathrm{Cs}^{+}$. Right figure: In typical soils, the concentration of $\mathrm{K}^{+} /$the concentration of $\mathrm{Cs}^{+}$in soil solution is higher than $10^{3}$. When the $\mathrm{K}^{+}$ concentration in the hydroponic solution is $0-100 \mu \mathrm{M}$ and the $\mathrm{Cs}^{+}$concentration is fixed at $75 \mathrm{nM}$, the rate of Cs ${ }^{+}$uptake into the root of the OsHAK1 mutant is reduced to $1 / 8$ or less compared to the wild type. In addition, the rate of the slight Cs uptake is constant regardless of the $\mathrm{K}^{+}$concentration of the hydroponic solution.

realistic soil conditions and HAK transporters carry the residual $\mathrm{Cs}^{+}$influx. In this section, we verify whether the $\mathrm{Cs}^{+}$and $\mathrm{K}^{+}$ uptake in rice fits this model, which involves HAK, KIR channels, and VIC channels.

\section{Function of $\mathrm{HAK}$ in $\mathrm{Cs}^{+}$and $\mathrm{K}^{+}$Uptake by the Roots of Rice Plants}

In rice grown in a hydroponic solution with normal soil $\mathrm{K}^{+}$ concentration $(0-100 \mu \mathrm{M})$, OsHAK1 absorbed most $\mathrm{Cs}^{+}$into the roots. When $\mathrm{K}^{+}$concentration in the hydroponic solution increased, the amount of $\mathrm{Cs}^{+}$uptake into the roots decreased drastically due to competition with $\mathrm{K}^{+}$. At $\mathrm{K}^{+}$concentrations above $1 \mathrm{mM}$, there was no difference in $\mathrm{Cs}^{+}$uptake between wild-type and OsHAK1 mutant (Rai et al., 2017). When the $\mathrm{K}^{+}$ concentration was increased from $14 \mu \mathrm{M}$ to $1.1 \mathrm{mM}$, the $\mathrm{Cs}^{+}$ uptake was reduced from 2.8 to $0.13 \mu \mathrm{g} \mathrm{g}^{-1}$ roots, and it did not decrease further (Figure 5 right panel). It is assumed that even at high $\mathrm{K}^{+}$concentrations, a small amount of $\mathrm{Cs}^{+}$is carried into the roots by transporters other than the $\mathrm{K}^{+}$transporter. The predicted mechanism of $\mathrm{Cs}^{+}$uptake under high $\mathrm{K}^{+}$condition is described in section "Function of VIC Channels in Cs ${ }^{+}$Uptake by the Roots of Rice Plants" (Rai et al., 2017).

In the simulation by White and Broadley (2000), at $\mathrm{K}^{+}$ concentrations between $10 \mu \mathrm{M}$ and $1 \mathrm{mM}$, the $\mathrm{Cs}^{+}$influx $\left(\mathrm{Cs}^{+}\right.$ concentration: $0.1 \mu \mathrm{M}$ ) is reduced to only about $1 / 4$. Bossemeyer et al. (1989) reported that the KUP transporter in Escherichia coli has a $K_{\mathrm{m}}$ of $5 \mathrm{mM}$ for $\mathrm{Cs}^{+}$transport and a $K_{\mathrm{m}}$ of $0.37 \mathrm{mM}$ for $\mathrm{K}^{+}$ transport. The simulation was based on the fact that $K_{\mathrm{m}}$ of HAK for $\mathrm{Cs}^{+}$transport is 10 -fold higher than the $K_{\mathrm{m}}$ for $\mathrm{K}^{+}$transport.

However, Bañuelos et al. (2002) analyzed the $\mathrm{Cs}^{+}$transport functions of OsHAK1 in heterologous expression and revealed that the yeast-expressed chimeric OsHAK1 (a part of the barley HvHAK1 sequence was added to the incomplete OsHAK1 cDNA) can transport $\mathrm{Cs}^{+}$and $\mathrm{K}^{+}$with a $K_{\mathrm{m}}$ of 11 and $6 \mu \mathrm{M}$, respectively. Thus, the difference in $K_{\mathrm{m}}$ for $\mathrm{Cs}^{+}$and $\mathrm{K}^{+}$transport may be smaller (Cs: up to 2 -fold, $\mathrm{K}^{+}$: up to 11 -fold) compared with the difference predicted by their model (White and Broadley, 2000; Bañuelos et al., 2002).

OsHAK1 is a high-affinity transporter that contributes to $\mathrm{K}^{+}$uptake mainly under low $\mathrm{K}^{+}$concentration, but under extracellular $\mathrm{K}^{+}$deficiency, the expression levels of this 
transporter in the roots increase several-fold (Okada et al., 2008, 2018; Nieves-Cordones et al., 2016). Thus, the responses of rice plants indicate that the contribution of HAK (OsHAK1) to $\mathrm{Cs}^{+}$ uptake may be higher than predicted by their model.

\section{Function of KIR Channels (OsAKT1) in $\mathrm{Cs}^{+}$and $\mathrm{K}^{+}$Uptake by the Roots of Rice Plants}

Deletion of OsHAK1 drastically reduces $\mathrm{Cs}^{+}$uptake, but the $\mathrm{K}^{+}$ uptake rates do not differ greatly between the OsHAK1 mutant and the wild type. This was attributed to other systems, which are involved in $\mathrm{K}^{+}$absorption into the roots, but contributed much less to $\mathrm{Cs}^{+}$uptake in OsHAK1 mutants. In rice roots, OsHAK1 and OsAKT1 mediate the $\mathrm{K}^{+}$uptake according to the extracellular $\mathrm{K}^{+}$concentration (Nieves-Cordones et al., 2016). In oshak1, probably most of $\mathrm{K}^{+}$that is typically absorbed by OsHAK1 is transported by OsAKT1. Although the KIR channel is a low affinity $\mathrm{K}^{+}$uptake system, the overexpression of OsAKT1 could improve the $\mathrm{K}^{+}$uptake under $100 \mu \mathrm{M}$ $\mathrm{K}^{+}$conditions. OsAKT1-mediated $\mathrm{K}^{+}$flux may be small but can generate a sizeable contribution over prolonged periods (Ahmad et al., 2016).

The current of KAT1 in Arabidopsis, a kind of KIR, is blocked by $\mathrm{Cs}^{+}$; it was reduced by $20 \%$ at $\mathrm{Cs}^{+}$concentration of $0.1 \mathrm{mM}$, and by $50 \%$ at $0.5 \mathrm{mM} \mathrm{Cs}^{+}$(Ichida and Schroeder, 1996). However, because the concentration of ${ }^{133} \mathrm{Cs}$ in the soil solution (below $\mathrm{Cs}^{+}$: $10 \mathrm{ppb}, 75 \mathrm{nM}$ ) is considerably lower than the concentration of $\mathrm{Cs}^{+}$examined in these studies, it is likely that OsAKT1 is not blocked by $\mathrm{Cs}^{+}$and thus can complement for the loss of $\mathrm{K}^{+}$absorption caused by the absence of OsHAK1. In addition, as we discuss below, it is almost certain that OsAKT1 does not contribute to $\mathrm{Cs}^{+}$influx because the remaining $\mathrm{Cs}^{+}$ uptake is not affected by $\mathrm{K}^{+}$.

\section{Function of VIC Channels in $\mathrm{Cs}^{+}$Uptake by the Roots of Rice Plants}

Even with OsHAK1 knockout, a small amount of $\mathrm{Cs}^{+}$was incorporated into rice roots. The residual $\mathrm{Cs}^{+}$uptake in OsHAK1 mutant was not affected by the extracellular $\mathrm{K}^{+}$ concentration. The model proposed by White and Broadley (2000) showed that a high amount of $\mathrm{Cs}^{+}$entered into the roots through the VIC channels. A relative permeability sequence of $\mathrm{K}^{+}: \mathrm{Rb}^{+}: \mathrm{Cs}^{+}: \mathrm{Na}^{+}: \mathrm{Li}^{+}$of 1.00:1.00:0.85:0.73:0.71 $\left(\mathrm{K}^{+}=\mathrm{Rb}^{+}>\mathrm{Cs}^{+}>\mathrm{Na}^{+}>\mathrm{Li}^{+}\right)$was given by the electrical conductance measurements of the VIC channels on the plasma membrane in the rye roots (White and Tester, 1992). In wheat roots, the selectivity relative to $\mathrm{Na}^{+}$was $\mathrm{NH}_{4}^{+}(2.06)>\mathrm{Rb}^{+}$ (1.38) $>\mathrm{K}^{+}(1.23)=\mathrm{Cs}^{+}(1.18)>\mathrm{Li}^{+}(0.83)>\mathrm{TEA}^{+}$ $(0.21)=\mathrm{Ca}^{2+}(0.21)$ (Davenport and Tester, 2000). On the basis of the results, $\mathrm{Cs}^{+}$permeability via the VIC channels is much higher than that via KIR channels. Cation influx through the VIC channels is partly inhibited by $\mathrm{Ca}^{2+}, \mathrm{Ba}^{2+}$, and other divalent ions (Roberts and Tester, 1997; White, 1997, 1999; Davenport and Tester, 2000).

These characteristics of VIC channels correspond to the inhibition of $\mathrm{Cs}^{+}$influx of the plants by divalent ions (Handley and Overstreet, 1961; Smolders et al., 1997). Therefore, the uptake of residual $\mathrm{Cs}^{+}$in rice roots may have occurred through the VIC channels.

However, the contribution of the VIC channels in rice roots was considerably lower than that of OsHAK1, which was the opposite of what was predicted by their model. A possible reason is that the $\mathrm{Cs}^{+}$concentration in soil solution was lower than that assumed in their model. Given that the amount of $\mathrm{Cs}^{+}$uptake varies greatly depending on the extracellular $\mathrm{K}^{+}$concentration, the contribution of each transporter to $\mathrm{Cs}^{+}$uptake depends greatly on the value of extracellular $\mathrm{K}^{+}$concentration that is assumed standard. For example, if $\mathrm{K}^{+}$concentration is high, the contribution of HAK is lower and the contribution of other transporters (such as VIC channels) becomes high. Therefore, in this review, we discussed the contribution of each transporter to $\mathrm{Cs}^{+}$uptake under $\mathrm{K}^{+}$and $\mathrm{Cs}^{+}$concentrations typically found in actual soils.

The other reason for the discrepancy between the model and our results is that rice plants have remarkably high silica content. Rice plants actively absorb silicic acid, and its content in the stem and leaves ranges from 10 to $20 \%$. In contrast, $\mathrm{Ca}^{2+}$ content of rice plants $(0.3$ to $0.4 \%$, w/w) is lower than that recorded in other plants (average of $1.57 \%$ ). Therefore, it was suggested that the $\mathrm{Ca}^{2+}$ concentration in the rhizosphere or apoplast of rice plants is higher than that in other plants because rice plants do not absorb high amounts of $\mathrm{Ca}^{2+}$. Future research should analyze which VIC channels are involved in $\mathrm{Cs}^{+}$uptake into the roots by means of molecular techniques, mutations, or other methods.

Thus, the results of rice analysis indicated that, under normal soil conditions, OsHAK1 mediate $80-90 \%$ of $\mathrm{Cs}^{+}$uptake into the roots and the rest is mediated by VIC channels (Rai et al., 2017; Figure 6-(5)(6). The proportion each transporter contributed to the Cs uptake was different, but they mostly agreed with the prediction by White and Broadley (2000).

\section{SUMMARY OF THE DYNAMICS OF RADIO-Cs FROM SOIL TO PLANTS}

The key point in the dynamics of radio-Cs in soils is its immobilization in soils. The amount of frayed edge sites in soils have significant effects on the radio-Cs uptake by plants. The free radio-Cs strongly binds to frayed edge sites in the soil, which decreases available radio-Cs for plants with time. This phenomenon is important for predicting the radio-Cs uptake of plants in addition to the decay of radioactivity of ${ }^{134,137} \mathrm{Cs}$ in soils (Figure 6 (1)).

In the dynamics of radio-Cs from soils to plants, the concentration of $\mathrm{K}^{+}$in soil solution affects the radio-Cs uptake into plants because $\mathrm{K}^{+}$and $\mathrm{Cs}^{+}$compete for absorption into plant roots. While the available $\mathrm{K}^{+}$concentration in soils increases, the $\mathrm{Cs}^{+}$uptake by plants decreases drastically (Zhu and Smolders, 2000; Kato et al., 2015; Kohyama et al., 2015; Kondo et al., 2015). Therefore, the application of potassium fertilizers is effective for preventing the agricultural crops from absorbing radio-Cs in contaminated fields (Figure 6 (2)). 


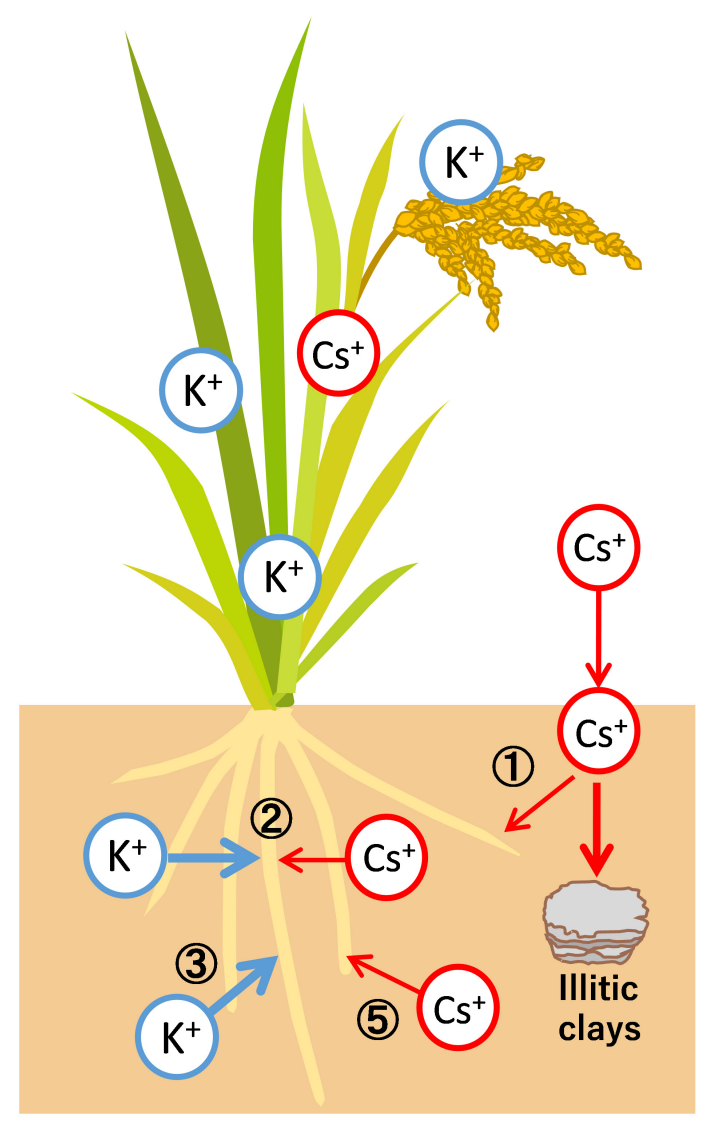

(3)

$\mathrm{K}^{+}$transport model

(4)

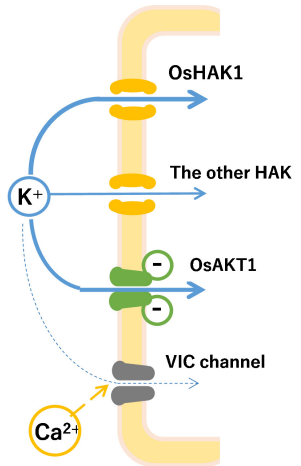

(5)
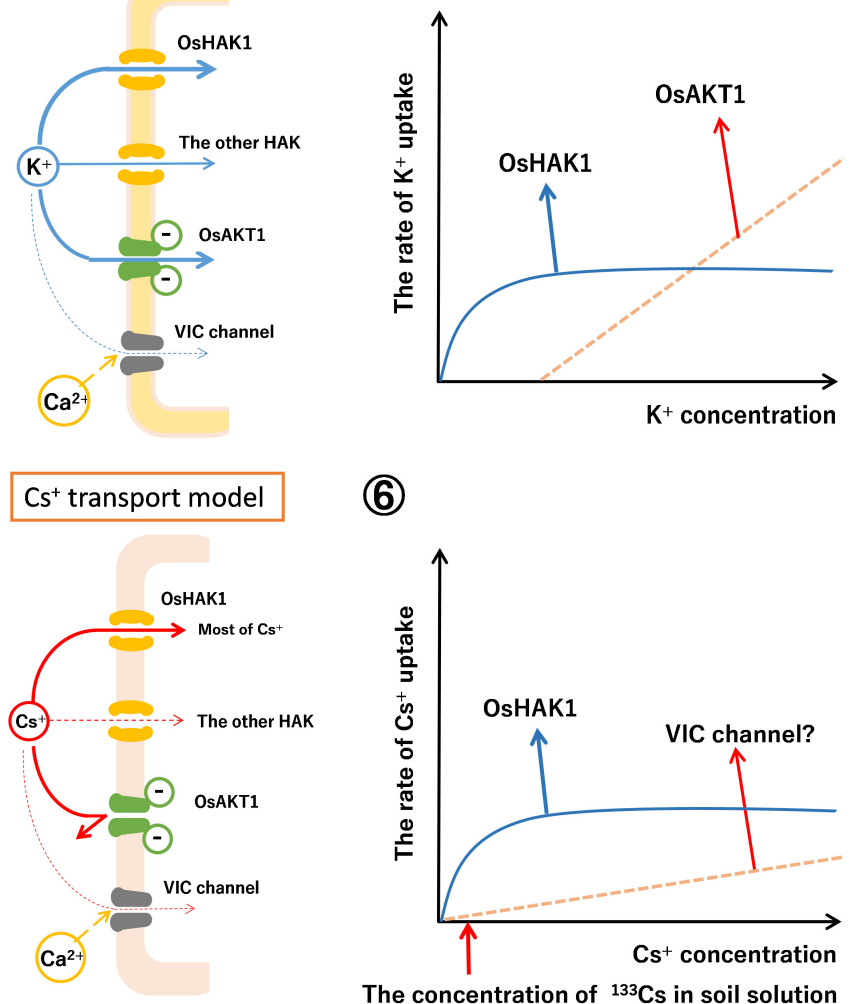

(6)

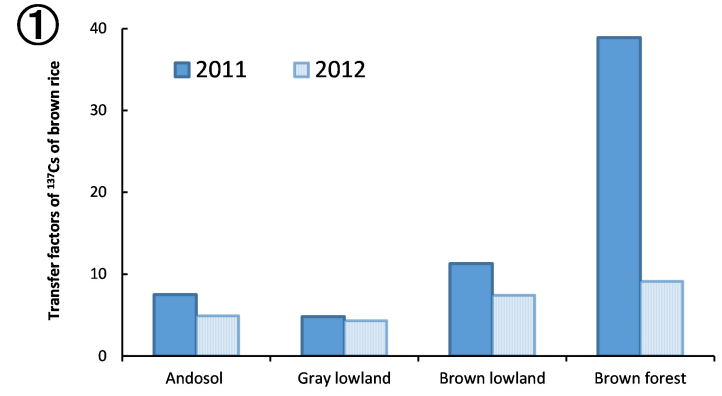

(2)

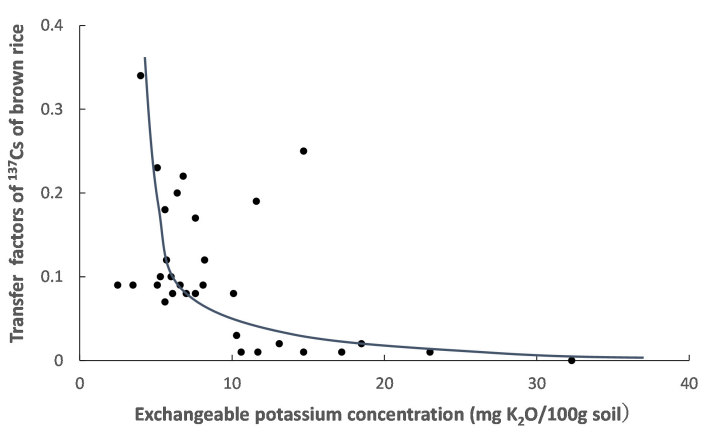

FIGURE 6 | Dynamics of radioactive Cs between soil and plant (using rice as an example). The dynamics of $\mathrm{Cs}^{+}$in soils was mainly affected by the specific adsorption to soil clay material (frayed edge sites of mica) and the competition with $\mathrm{K}^{+}$in the uptake by plants. As described in Figure 2, the newly entered Cs ${ }^{+}$ $\left(\right.$ radio $\mathrm{Cs}^{+}$) would be eventually immobilized. Therefore, available $\mathrm{Cs}^{+}$and its transfer factors in the rice grains decreased yearly (1)). The graph is drawn from the data of Fujimura et al. (2015). The relationship between the soils-to-rice-plant transfer factors and the concentration of exchangeable potassium in soils was shown (2). The $\mathrm{K}^{+}$and $\mathrm{Cs}^{+}$compete for absorption by the rice roots. While exchangeable (plant-available) $\mathrm{K}^{+}$in soils increased, the $\mathrm{Cs}^{+}$concentrations in rice grains decreased drastically. The graph is drawn from the data of Kohyama et al. (2015). The $\mathrm{K}^{+}$and $\mathrm{Cs}^{+}$uptake in rice plants by the membrane transporters is estimated. In (3), the mode of $\mathrm{K}^{+}$uptake in the roots of rice plants is proposed. $\mathrm{K}^{+}$uptake is mainly through OsHAK1 and OsAKT1. In (4), the $\mathrm{K}^{+}$uptake curve is composed of two distinct transporter systems as shown by Epstein (1972). The solid line indicates the rate of $\mathrm{K}^{+}$uptake by OsHAK1 in rice while the dotted line indicates the $\mathrm{K}^{+}$ influx through OsAKT1 channel. The rest of $\mathrm{K}^{+}$uptake is contributed by the other $\mathrm{K}^{+}$transporters. In (5), the mode of Cs ${ }^{+}$uptake is proposed. Cs ${ }^{+}$uptake is through OsHAK1 and the VIC channel. In (6), the $\mathrm{Cs}^{+}$uptake curve also consists of two Michaelis-Menten hyperbolae as shown by Shaw and Bell (1989). The solid line indicates the rate of $\mathrm{Cs}^{+}$uptake by OsHAK1 in rice and the dotted line indicates potential $\mathrm{Cs}^{+}$influx through the VIC channel. Since the $\mathrm{Cs}^{+}$concentration in typical soil solution is lower than $75 \mathrm{nM}\left(10 \mathrm{ppb}:{ }^{133} \mathrm{Cs}\right.$, as the red arrow indicates), it is estimated that most of the $\mathrm{Cs}^{+}$uptake in rice is absorbed by OsHAK1 and the rest through the VIC channel as the latter does not compete with $\mathrm{K}^{+}$.

Increasing the $\mathrm{K}^{+}$concentration in the rhizosphere is also important because it regulates the expression of HAK, which absorb $\mathrm{Cs}^{+}$into the roots.
In rice roots, OsHAK1 and OsAKT1 mediate the $\mathrm{K}^{+}$ uptake according to the extracellular $\mathrm{K}^{+}$concentration (NievesCordones et al., 2016; Figure 6 (3). The $\mathrm{K}^{+}$uptake curve is 
divided into the two hyperbolae (Epstein, 1972). The $\mathrm{K}^{+}$uptake under low $\mathrm{K}^{+}$concentration depends upon OsHAK1, and the $\mathrm{K}^{+}$ influx under high $\mathrm{K}^{+}$levels is mediated mainly by the OsAKT1 channel (Figure 6 (4)).

The $\mathrm{Cs}^{+}$uptake curve in wheat at $200 \mu \mathrm{M} \mathrm{Cs}{ }^{+}$could also be described by the sum of two Michaelis-Menten hyperbolae (Shaw and Bell, 1989). It is estimated that most of the $\mathrm{Cs}^{+}$uptake in rice is via OsHAK1 under normal soil $\mathrm{K}^{+}$concentrations. Permeability of KIR channels to $\mathrm{Cs}^{+}$is lower than that to $\mathrm{K}^{+}$; practically, $\mathrm{Cs}^{+}$can hardly permeate. The residual $\mathrm{Cs}^{+}$influx into roots does not compete with $\mathrm{K}^{+}$, suggesting that it may be via transporters not involved in $\mathrm{K}^{+}$uptake (Figure 6 (5)). The uptake of low affinity $\mathrm{Cs}^{+}$is inhibited by divalent cations (Handley and Overstreet, 1961), whereas the permeability of monovalent cations through VIC channel is partly inhibited by $\mathrm{Ca}^{2+}$ (Davenport and Tester, 2000). It is reasonable to conclude that the residual $\mathrm{Cs}^{+}$influx is through VIC channels (Figure 6 (6)).

\section{CONCLUSION}

Humans have experienced extensive radionuclide contamination from atmospheric nuclear tests and the two nuclear power plant accidents. Nuclear tests in the atmosphere have already been prohibited, but the nuclear power accounts for $10 \%$ of global electricity production. Therefore, the risk of nuclear incidents must be considered and we must cope with the risks. RadioCs $\left({ }^{134,137} \mathrm{Cs}\right)$ described in this review, is produced in large amounts in the reactor core. It has a low boiling point and easily diffuses into the environment after accidents. Furthermore, it has a long half-life and strongly adsorbs to soil, remaining in the

\section{REFERENCES}

Ahmad, I., Mian, A., and Maathuis, F. M. J. (2016). Overexpression of the rice AKT1 potassium channel affects potassium nutrition and rice drought tolerance. J. Exp. Bot. 67, 2689-2698. doi: 10.1093/jxb/erw103

Alemán, F., Caballeo, F., Ródenas, R., Rivero, R. M., Martínez, V., and Rubio, F. (2014). The F130S point mutation in the Arabidopsis high-affinity $\mathrm{K}+$ transporter AtHAK5 increases $\mathrm{K}+$ over $\mathrm{Na}+$ and $\mathrm{Cs}+$ selectivity and confers $\mathrm{Na}+$ and $\mathrm{Cs}+$ tolerance to yeast under heterologous expression. Front. Plant Sci. 5:430. doi: $10.3389 /$ fpls.2014.00430

Almgren, S., and Isaksson, M. (2006). Vertical migration studies of 137Cs from nuclear weapons fallout and the Chernobyl accident. J. Environ. Radioact. 91, 90-102. doi: 10.1016/j.jenvrad.2006.08.008

Amrutha, R. N., Sekhar, P. N., Varshney, R. K., and Kishor, P. B. K. (2007). Genome-wide analysis and identification of genes related to potassium transporter families in rice (Oryza sativa L.). Plant Sci. 172, 708-721.8.

Ashley, M. K., Grant, M., and Grabov,A. (2005). Plant responses to potassium deficiencies: a role for potassium transport proteins. J. Exp. Bot. 57, 425-436. doi: $10.1093 /$ jxb/erj034

Bange, G. G. J., and Overstreet, R. (1960). Some observations on absorption of cesium by excised barley roots. Plant Physiol. 35, 605-608. doi: 10.1104/pp.35. 5.605

Bañuelos, M. A., Garciadeblas, B., Cubero, B., and Rodríguez-Navarro, A. (2002). Inventory and functional characterization of the HAK potassium transporters of rice. Plant Physiol. 130, 784-795. doi: 10.1104/pp.007781

Beresford, N. A., Fesenko, S., Konoplev, A., Skuterudd, L., Smithe, J. T., and Voigt, G. (2016). Thirty years after the chernobyl accident: what lessons have we learnt? J. Environ. Radioact. 157, 77-89. doi: 10.1016/j.jenvrad.2016.02.003 environment for a long time. In unforeseen circumstances, radio Cs can be absorbed by plants and enter the food chain.

Since Fukushima, numerous studies have been conducted in Japan, including those on radio-Cs dynamics in the environment, radionuclide testing of agricultural products, and the cultivation of various crops. In addition, our understanding of the mechanism of $\mathrm{Cs}^{+}$uptake in rice has rapidly progressed owing to the implementation of genetic and molecular techniques such as mutations and genome editing. As shown in this review, many researchers have conducted hydroponics experiments with various ion conditions, heterologous expression analysis of $\mathrm{K}^{+}$ transporters using Xenopus oocyte and yeast, electrophysiological analysis using microelectrodes, and analysis of mutants by forward and reverse genetics. Thus, different pathways were implemented to elucidate the entire mechanism of $\mathrm{Cs}^{+}\left(\mathrm{K}^{+}\right)$ uptake and transport. These experimental results are expected to reveal the $\mathrm{Cs}^{+}$dynamics in soil, from soil to plant, and in individual plants. They will also lead to deeper understanding of the risks of nuclear power plants (problems caused by radio-Cs) to soil-plant ecosystems.

\section{AUTHOR CONTRIBUTIONS}

HR and MK made substantial direct and intellectual contribution to this work and approved the manuscript for publication.

\section{FUNDING}

This work was supported by the JSPS KAKENHI Grant Number JP19H04272.

Beresford, N. A., Robert, W., Mayes, R. W., Cooke, A. I., Barnett, C. L., Howard, B. J., et al. (2000). The Importance of source-dependent bioavailability in determining the transfer of Ingested radionuclides to ruminant-derived food products. Am. Chem. Soc. 34, 4455-4462. doi: 10.1021/es0000697

Bossemeyer, D., Schlösser, A., and Bakker, E. P. (1989). Specific cesium transport via the Escherichia coli kup (TrkD) K+ uptake system. J. Bacteriol. 171, 22192221. doi: $10.1128 / \mathrm{jb} \cdot 171.4 .2219-2221.1989$

Bregante, M., Carpaneto, A., Pastorino, F., and Gambale, F. (1997). Effects of mono- and multi-valent cations on the inward-rectifying potassium channel in isolated protoplasts from maize roots. Eur. Biophys. J. 26, 381-391. doi: 10.1007/s002490050092

Broadley, M. R., Escobar-Gutiérrez, A. J., Bowen, H. C., Willey, N. J., and White, P. J. (2001). Influx and accumulation of Cs+ by the akt1 mutant of Arabidopsis thaliana (L.) Heynh. lacking a dominant $\mathrm{K}+$ transport system. J. Exp. Bot. 52, 839-844. doi: 10.1093/jexbot/52.357.839

Caballero, F., Botella, M. A., Rubio, L., Fernández, J. A., Martínez, V., and Rubio, F. (2012). A Ca2+-sensitive system mediates low-affinity $\mathrm{K}+$ uptake in the absence of AKT1 in Arabidopsis Plants. Plant Cell Physiol. 53, 2047-2059. doi: $10.1093 / \mathrm{pcp} / \mathrm{pcs} 140$

Chen, G., Hu, Q., Luo, L., Yang, T., Zhang, S., Hu, Y., et al. (2015). Rice potassium transporter OsHAK1 is essential for maintaining potassium-mediated growth and functions in salt tolerance over low and high potassium concentration ranges. Plant Cell Environ. 38, 2747-2765. doi: 10.1111/pce.12585

Chino, M., Nakayama, H., Nagai, H., Terada, H., Katata, G., and Yamazawa, H. (2011). Preliminary estimation of release amounts of ${ }^{131} \mathrm{I}$ and ${ }^{137} \mathrm{Cs}$ accidentally discharged from the Fukushima Daiichi nuclear power plant into the atmosphere. J. Nucl. Sci. Technol. 48, 1129-1134. doi: 10.1080/18811248. 2011.9711799 
Collander, R. (1941). Selective absorption of cations by higher plants. Plant Physiol. 16, 691-720. doi: 10.1104/pp.16.4.691

Cremers, A., Elsen, A., Preter, P. D., and Maes, A. (1988). Quantitative analysis of radiocaesium retention in soils. Nature 335, 247-249. doi: 10.1038/335247a0

Davenport, R. J., and Tester, M. (2000). A weakly voltage-dependent, nonselective cation channel mediates toxic sodium influx in wheat. Plant Physiol. 122, 823-834. doi: 10.1104/pp.122.3.823

Dreyer, I., Horeau, C., Lemaillet, G., Zimmermann, S., Bush, D. R., RodríguezNavarro, A., et al. (1999). Identification and characterization of plant transporters using heterologous expression systems. J. Exp. Bot. 50, 1073-1087. doi: 10.1093/jexbot/50.suppl_1.1073

Epstein, E. (1972). Mineral Nutrition of Plants : Principles and Perspectives. New York, NY: Wiley.

Fesenko, S., Isamov, N., Barnett, C. L., Beresford, N. A., Howard, B. J., Sanzharova, N., et al. (2015). Review of Russian language studies on radionuclide behaviour in agricultural animals: biological half-lives. J. Environ. Radioact. 142, 136-151. doi: 10.1016/j.jenvrad.2015.01.015

Fesenko, S. V., Alexakhin, R. M., Balonov, M. I., Bogdevitch, I. M., Howard, B. J., Kashparov, V. A., et al. (2007). An extended critical review of twenty years of countermeasures used in agriculture after the Chernobyl accident. Sci. Total Environ. 383, 1-24. doi: 10.1016/j.scitotenv.2007.05.011

Fujimura, S., Muramatsu, Y., Ohno, T., Saitou, M., Suzuki, Y., Kobayashi, T., et al. (2015). Accumulation of $137 \mathrm{Cs}$ by rice grown in four types of soil contaminated by the Fukushima Dai-ichi nuclear power plant accident in 2011 and 2012. J. Environ. Radioact. 140, 59-64. doi: 10.1016/j.jenvrad.2014.10.018

Gaymard, F., Pilot, G., Lacombe, B., Bouchez, D., Bruneau, D., Boucherez, J., et al. (1998). Identification and disruption of a plant shaker-like outward channel involved in $\mathrm{K}+$ release into the xylem sap. Cell 94, 647-655.

Gierth, M., Mäser, P., and Schroeder, J. I. (2005). The potassium transporter AtHAK5 functions in $\mathrm{K}+$ deprivation-induced high-affinity $\mathrm{K}+$ uptake and AKT1 K+ channel contribution to $\mathrm{K}+$ uptake kinetics in Arabidopsis roots. Plant Physiol. 137, 1105-1114.

Gomez-Porras, J. L., Riaño-Pachón, D. M., Benito, B., Haro, R., Sklodowski, K., Rodríguez-Navarro, A., et al. (2012). Phylogenetic analysis of K+ transporters in bryophytes, lycophytes, and flowering plants indicates a specialization of vascular plants. Front. Plant Sci. 3:167. doi: 10.3389/fpls.2012.00167

Gupta, M., Qiu, X., Wang, L., Xie, W., Zhang, C., Xiong, L., et al. (2008). KT/HAK/KUP potassium transporters gene family and their whole-life cycle expression profile in rice (Oryza sativa). Mol. Genet. Genomics 280, 437-452. doi: 10.1007/s00438-008-0377-7

Hampton, C. R., Bowen, H. C., Broadley, M. R., Hammond, J. P., Mead, A., Payne, K. A., et al. (2004). Cesium toxicity in Arabidopsis. Plant Physiol. 136, 3824-3837. doi: 10.1104/pp.104.046672

Handley, R., and Overstreet, R. (1961). Effect of various cations upon absorption of carrier-free cesium. Plant Physiol. 36, 66-69. doi: 10.1104/pp.36.1.66

Henrichs, K., Paretzke, H. G., Voigt, G., and Berg, D. (1989). Measurements of Cs absorption and retention in man. Health Phys. 57, 571-578.

Ichida, A. M., and Schroeder, J. I. (1996). Increased resistance to extracellular cation block by mutation of the pore domain of the Arabidopsis inward-rectifying K+ channel KAT1. J. Membrane Biol. 151, 53-62.

Imanaka, T. (2016). Chernobyl and Fukushima: comparison of accident process and radioactive contamination. Kagaku 86, 252-257. doi: 10.1093/jrr/rr v074

International Atomic Energy Agency [IAEA] (2003-2005). Chernobyl's Legacy: Health, Environmental, and Socio-economic Impacts, and Recommendations to the Governments of Belarus, the Russian Federation, and Ukraine. The Chernobyl Forum. ed. Kinly III (Vienna: International Atomic Energy Agency [IAEA]).

Ishikawa, S., Hayashi, S., Abe, T., Igura, M., Kuramata, M., Tanikawa, H., et al. (2017). Low-cesium rice: mutation in OsSOS2 reduces radiocesium in rice grains. Sci. Rep. 7:2432. doi: 10.1038/s41598-01702243-9

Johansson, I., Wulfetange, K., Porée, F., Michard, E., Gajdanowicz, P., Lacombe, B., et al. (2006). External K+ modulates the activity of the Arabidopsis potassium channels SKOR via an unusual mechanism. Plant J. 46, 269-281.

Kato, N., Kihou, N., Fujimura, S., Ikeba, M., Miyazaki, N., Saito, Y., et al. (2015). Potassium fertilizer and other materials as countermeasures to reduce radiocesium levels in rice: results of urgent experiments in 2011 responding to the Fukushima Daiichi Nuclear Power Plant accident. Soil Sci. Plant Nutr. 61, 179-190.

Kitagawa, Y., Yanai, J., and Nakao, A. (2017). Evaluation of nonexchangeable potassium content of agricultural soils in Japan by the boiling HNO3 extraction method in comparison with exchangeable potassium. Soil Sci. Plant Nutr. 64, $116-122$.

Kohyama, K., Obara, H., Takata, Y., Saito, T., Sato, M., Yoshioka, K., et al. (2015). Soil properties for analyzing cause of high radiocesium concentration in brown rice produced. Bull. Natl. Inst. Agroenviron. Sci. 34, 63-73.

Kondo, M., Maeda, H., Goto, A., Nakano, H., Kiho, N., Makino, T., et al. (2015). Exchangeable $\mathrm{Cs} / \mathrm{K}$ ratio in soil is an index to estimate accumulation of radioactive and stable Cs in rice plant. Soil Sci. Plant Nutr. 61, 133-143. doi: 10.1080/00380768.2014.973347

Maathuis, F. J. M. (2009). Physiological functions of mineral macronutrients. Curr. Opin. Plant Biol. 12, 250-258. doi: 10.1016/j.pbi.2009.04.003

Maathuis, F. J. M., and Sanders, D. (1994). Mechanism of high-affinity potassium uptake in roots of Arabidopsis thaliana. Proc. Natl. Acad. Sci. U.S.A. 91, 9272-9276.

Maathuis, F. J. M., and Sanders, D. (1995). Contrasting roles in ion transport of two $\mathrm{K}+$-channel types in root cells of Arabidopsis thaliana. Planta 197, 456-464.

Mäser, P., Thomine, S., Schroeder, J. I., Ward, J. M., Hirschi, K., Sze, H., et al. (2001). Phylogenetic relationships within cation transporter families of Arabidopsis. Plant Physiol. 126, 1646-1667.

Nieves-Cordones, M., Martínez, V., Benito, B., and Rubio, F. (2016). Comparison between Arabidopsis and rice for main pathways of $\mathrm{K}+$ and $\mathrm{Na}+$ uptake by roots. Front. Plant Sci. 7:992. doi: 10.3389/fpls.2016.00992

Nieves-Cordones, M., Mohamed, S., Tanoi, K., Kobayashi, N. I., Takagi, K., Vernet, A., et al. (2017). Production of low-Cs+rice plants by inactivation of the $\mathrm{K}+$ transporter OsHAK1 with the CRISPR-Cas system. Plant J. 92, 43-56. doi: $10.1111 /$ tpj. 13632

Nihei, N. (2013). "Radioactivity in agricultural products in Fukushima," in Agricultural Implications of the Fukushima Nuclear Accident, eds T. M. Nakanishi and K. Tanoi (Tokyo: Springer), 73-85.

Noda, Y., Furukawa, J., Aohara, T., Nihei, N., Hirose, A., Tanoi, K., et al. (2016). Short day length-induced decrease of cesium uptake without altering potassium uptake manner in poplar. Sci. Rep. 6:38360. doi: 10.1038/srep38360

Ohmori, Y., Inui, Y., Kajiwara, M., Nakata, A., Sotta, N., Kasai, K., et al. (2014). Difference in cesium accumulation among rice cultivars grown in the paddy field in Fukushima Prefecture in 2011 and 2012. J. Plant Res. 127, 57-66. doi: 10.1007/s10265-013-0616-9

Okada, T., Nakayama, H., Shinmyo, A., and Yoshida, K. (2008). Expression of OsHAK genes encoding potassium ion transporters in rice. Plant Biotechnol. 25, 241-245.

Okada, T., Yamane, S., Yamaguchi, M., Kato, K., Shinmyo, A., Tsunemitsu, Y., et al. (2018). Characterization of rice KT/HAK/KUP potassium transporters and K+ uptake by HAK1 from Oryza sativa. Plant Biotechnol. 35, 101-111. doi: 10.5511/plantbiotechnology.18.0308a

Ono, Y., Sato, K., Sakuma, H., Nemoto, K., Tanoi, K., and Nakanishi, T. M. (2014). Variation in rice radiocesium absorption among different cultivars. Bull. Fukushima Agric. Technol. Cent. 48, 29-32.

Pyo, Y. J., Gierth, M., Schroeder, J. I., and Cho, M. H. (2010). High-affinity $\mathrm{K}+$ transport in Arabidopsis: AtHAK5 and AKT1 are vital for seedling establishment and postgermination growth under low-potassium conditions. Plant Physiol. 153, 863-875. doi: 10.1104/pp.110.154369

Qi, Z., Hampton, C. R., Shin, R., Barkla, B. J., White, P. J., and Schachtman, D. P. (2008). The high affinity $\mathrm{K}+$ transporter AtHAK5 plays a physiological role in planta at very low $\mathrm{K}+$ concentrations and provides a caesium uptake pathway in Arabidopsis. J. Exp. Bot. 59, 595-607. doi: 10.1093/jxb/erm330

Rai, H., Yokoyama, S., Satoh-Nagasawa, N., Furukawa, J., Nomi, T., Ito, Y., et al. (2017). Cesium uptake by rice roots largely depends upon a single gene, HAK1, which encodes a potassium transporter. Plant Cell Physiol. 58, 1486-1493. doi: $10.1093 / \mathrm{pcp} / \mathrm{pcx} 137$

Roberts, S. K., and Tester, M. (1997). A patch clamp study of Na+transport in maize roots. J. Exp. Bot. 48, 431-440. doi: 10.1093/jxb/48.Special_Issue.431

Rodríguez-Navarro, A. (2000). Potassium transport in fungi and plants. Biochim. Biophys. Acta 1469, 1-30.

Rubio, F., Alemán, F., Nieves-Cordones, M., and Martínez, V. (2010). Studies on Arabidopsis athak5, atakt1 double mutants disclose the range of concentrations 
at which AtHAK5, AtAKT1 and unknown systems mediate K+ uptake. Physiol. Plant. 139, 220-228. doi: 10.1111/j.1399-3054.2010.01354.x

Rubio, F., Nieves-Cordones, M., Alemán, F., and Martínez, V. (2008). Relative contribution of AtHAK5 and AtAKT1 to $\mathrm{K}+$ uptake in the high-affinity range of concentrations. Physiol. Plant. 134, 598-608. doi: 10.1111/j.1399-3054.2008. 01168.x

Shaw, G., and Bell, J. N. B. (1989). The Kinetics of Caesium absorption by roots of winter wheat and the possible consequences for the derivation of soil-to-plant transfer factors for radiocaesium. J. Environ. Radioact. 10, 213-231.

Shaw, G., and Bell, J. N. B. (1991). Competitive effects of potassium and ammonium on caesium uptake kinetics in wheat. J. Environ. Radioact. 13, 283-296.

Smolders, E., Sweeck, L., Merckx, R., and Cremers, A. (1997). Cationic interactions in radiocaesium uptake from solution by spinach. J. Environ. Radioact. 34, 161-170.

Sparks, D. L., and Huang, P. M. (1985). "physical chemistry of soil potassium," in Potassium in Agriculture, ed. R. D. Munson (Madison, WI: American Society of Agronomy), 201-276. doi: 10.2134/1985.potassium.c9

Szczerba, M. W., Britto, D. T., and Kronzucker, H. J. (2009). K+ transport in plants: physiology and molecular biology. J. Plant Physiol. 166, 447-466. doi: 10.1016/j.jplph.2008.12.009

Takahashi, J., Onda, Y., Hihara, D., and Tamura, K. (2019). Six-year monitoring of the vertical distribution of radiocesium in three forest soils after the Fukushima Dai-ichi nuclear power plant accident. J. Environ. Radioact. 192, 172-180. doi: 10.1016/j.jenvrad.2018.06.015

Tanoi, K., Nobori, T., Shiomi, S., Saito, T., Kobayashi, N. I., Leonhardt, N., et al. (2019). Cesium Translocation in Rice, Agricultural Implications of the Fukushima Nuclear Accident (III). Singapore: Springer, 15-25.

Tsukada, H., Hasegawa, H., Hisamatsu, S., and Yamasaki, S. (2002). Transfer of $137 \mathrm{Cs}$ and stable Cs from paddy soil to polished rice in Aomori, Japan. J. Environ. Radioact. 59, 351-363.

Vandebroek, L., Hees, M. V., Delvaux, B., Spaargaren, O., and Thiry, Y. (2012). Relevane of Radiocaesium Interception Potential (RIP) on a worldwide scale to assess soil vulnerability to 137 Cs contamination. J. Environ. Radioact. 104, 87-93. doi: 10.1016/j.jenvrad.2011.09.002

Wegner, L. H., and Raschke, K. (1994). Ion channels in the xylem parenchyma of barley roots. Plant Physiol. 105, 799-813.

White, P. J. (1997). Cation channels in the plasma membrane of rye roots. J. Exp. Bot. 48, 499-514. doi: 10.1093/jxb/48.Special_Issue.499

White, P. J. (1999). The molecular mechanism of sodium influx to root cells. Trends Plant Sci. 4, 245-247.

White, P. J., and Broadley, M. R. (2000). Mechanisms of caesium uptake by plants. New Phytol. 147, 241-256.

White, P. J., and Tester, M. A. (1992). Potassium channels from the plasma membrane of rye roots characterized following incorporation into planar lipid bilayers. Planta 186, 188-202. doi: 10.1007/BF00196248

Yamaguchi, N. (2014). Adsorption mechanism of radiocesium on soil. J. Jpn. Soc. Soilphys. 126, 11-21.

Yang, Z., Gao, Q., Sun, C., Li, W., Gu, S., and Xu, C. (2009). Molecular evolution and functional divergence of HAK potassium transporter gene family in rice (Oryza sativa L.). J. Genet. Genomics 36, 161-172. doi: 10.1016/S1673-8527(08) 60103-4

Zhu, Y. G., and Smolders, E. (2000). Plant uptake of radiocaesium: a review of mechanisms, regulation and application. J. Exp. Bot. 51, 1635-1645.

Conflict of Interest: The authors declare that the research was conducted in the absence of any commercial or financial relationships that could be construed as a potential conflict of interest.

Copyright (c) 2020 Rai and Kawabata. This is an open-access article distributed under the terms of the Creative Commons Attribution License (CC BY). The use, distribution or reproduction in other forums is permitted, provided the original author(s) and the copyright owner(s) are credited and that the original publication in this journal is cited, in accordance with accepted academic practice. No use, distribution or reproduction is permitted which does not comply with these terms. 